\title{
Middle-to-Upper Palaeolithic site formation processes at the Bordes-Fitte rockshelter (Central France)
}

\author{
Thierry Aubry ${ }^{\mathrm{a},{ }^{*}}$, Luca Antonio Dimuccio ${ }^{\mathrm{b}, \mathrm{c}}$, Jan-Pieter Buylaert ${ }^{\mathrm{d}, \mathrm{e}}$, Morgane Liard ${ }^{\mathrm{f}}$, \\ Andrew S. Murray ${ }^{\mathrm{e}}$, Kristina Jørkov Thomsen ${ }^{\mathrm{d}}$, Bertrand Walter ${ }^{\mathrm{g}}$ \\ a Fundação Côa Parque, Rua do Museu, 5150-610 Vila Nova de Foz Côa, Portugal \\ ${ }^{\mathrm{b}}$ CEGOT - Centro de Estudos em Geografia e Ordenamento do Território, Departamento de Geografia, Faculdade de Letras, Universidade de Coimbra, \\ Praça da Porta Férrea, 3004-530 Coimbra, Portugal \\ ${ }^{c}$ Departamento de Ciências da Terra, Faculdade de Ciências e Tecnologia, Universidade de Coimbra, Largo Marquês de Pombal, 3000-272 Coimbra, Portugal \\ d Radiation Research Division, Risø DTU, DK-4000 Roskilde, Denmark \\ e Nordic Laboratory for Luminescence Dating, Department of Earth Sciences, Aarhus University, Risø DTU, DK-4000 Roskilde, Denmark \\ ${ }^{\mathrm{f}} \mathrm{UMR} 6042$ GEOLAB, INRAP-Direction interrégionale Centre/Île-de-France, Base Orléans, France \\ ${ }^{g}$ Société d'Études et de Recherche sur le Paléolithique de la Vallée de la Claise, Les Chirons, 37290 Preuilly-sur-Claise, France
}

\section{A R T I C L E I N F O}

\section{Article history:}

Received 17 April 2014

Received in revised form

13 September 2014

Accepted 15 September 2014

Available online 5 October 2014

\section{Keywords:}

Middle-Upper Palaeolithic transition

Site formation processes

Lithic technology

Luminescence and radiocarbon dating

\begin{abstract}
A B S T R A C T
Transformation in technological patterns associated with the Middle-to-Upper Palaeolithic transition between 50 and $40 \mathrm{ka}$ in Western Europe and their relationship with the Neanderthal and Anatomically Modern Human populations and behaviors are issues that continue to stimulate heated debate. In this article we use the Middle and Early Upper Palaeolithic archaeo-stratigraphic record from the Bordes-Fitte rockshelter (les Roches d'Abilly site, Central France), a Bayesian analysis of the ages obtained by accelerator mass spectrometry radiocarbon on ultrafiltered collagen and by luminescence on quartz and feldspar grains, to establish a timeline for material culture and sedimentary dynamic changes during the Middle-to-Upper Palaeolithic transition. Technology, refitting studies and taphonomy of lithic artifacts recovered in the geoarchaeological field units D1 and D2 permit to characterize 3 reduction strategies (Levallois, Discoidal and Châtelperronian blade) that took place between the cold Heinrich events 5 and 4. We discuss the implications of the results to characterize the end of the Middle Palaeolithic, and for distinguishing anthropogenic and non-anthropogenic factors in Middle-to-Upper Palaeolithic assemblage's variability.
\end{abstract}

๑) 2014 Elsevier Ltd. All rights reserved.

\section{Introduction}

Changes in material culture associated with the Middle-toUpper Palaeolithic transition between 50 and $40 \mathrm{ka}$ in Western Europe, and their relationship with the Neanderthal and Anatomically Modern Human populations and behaviors are issues that continue to stimulate heated debate (Bordes, 1971; Howells, 1976; D'Errico et al., 1998; Mellars, 1996, 2005; Bar-Yosef and Bordes, 2010; Zilhão, 2013). Two main characteristics of the geoarchaeological record of this period could explain the difficulty in elaborating a reliable timeline with a resolution sufficient to understand material culture changes observed during this period.

Firstly, the key Middle-to-Upper Palaeolithic (MUP) sequences of Western-south France were affected by successive cold Heinrich events (HE) (Heinrich, 1988) that caused a periglacial environment

\footnotetext{
* Corresponding author.

E-mail address: thaubry@sapo.pt (T. Aubry).
}

along the Atlantic continental margin (Sanchez-Goñi and Harrison, 2010), propitious to erosive processes attested by stratigraphical disconformities and post-depositional disturbances in archaeostratigraphic sequences (Bertran et al., 2010; Goldberg and Macphail, 2006). Lithic assemblage technology and typology (Rigaud, 1996), refitting between lithic (Bordes, 2003; Bachellerie, 2011) or faunal remains (Morin et al., 2005; Discamps et al., 2012), surface damage analysis correlated with technological study of lithic remains (Zilhão et al., 2006; Villa and Soressi, 2000; Soressi, 2011), and study of patterns in the orientation of elongated artefacts (Bertran et al., 1997; Lenoble and Bertran, 2004; McPherron, 2005) have been applied to evaluate mixing disturbances and stratigraphic coherence for MUP archaeological assemblages. However, these taphonomic analyses have been realized independently of the reconstruction of sedimentary and pedogenic processes, and have yet to be applied systematically to the key MUP sequences in order to establish the relationship between dated samples and occupation by human or carnivores (Zilhão, 2013). 
Secondly, the limitations of ${ }^{14} \mathrm{C}$ dating beyond $35 \mathrm{ka}$ cal BP have been proven by studies which have re-dated sites using AMS radiocarbon dating with ultrafiltration. These have systematically revealed older results compared to those obtained when other pretreatment chemical methods were applied (Higham et al., 2006; Jacobi et al., 2006). Despite some controversies (Hüls et al., 2007; Hublin et al., 2012), using this sample preparation protocol is leading to the creation of a new chronological framework for the Late Middle Palaeolithic (LMP) and Early Upper Palaeolithic (EUP) in Western Europe (Gravina et al., 2005; Hublin et al., 2012;
Higham, 2011; Higham et al., 2010, 2011, 2014; McPherron et al., 2012; Richter et al., 2013; Talamo et al., 2012). Until very recently, there are still few cases of application of the ultrafiltration protocol to date occupations corresponding to the very end of the Middle Palaeolithic in Europe (Higham et al., 2014), and most of the contexts attributed to this period were based on lithic technology, faunal biozonation or their relative position in archaeostratigraphic sequences (Jaubert et al., 2011).

Les Roches d'Abilly is an archaeological site located in Central France, along the Creuse Valley, that consists of small, horizontal

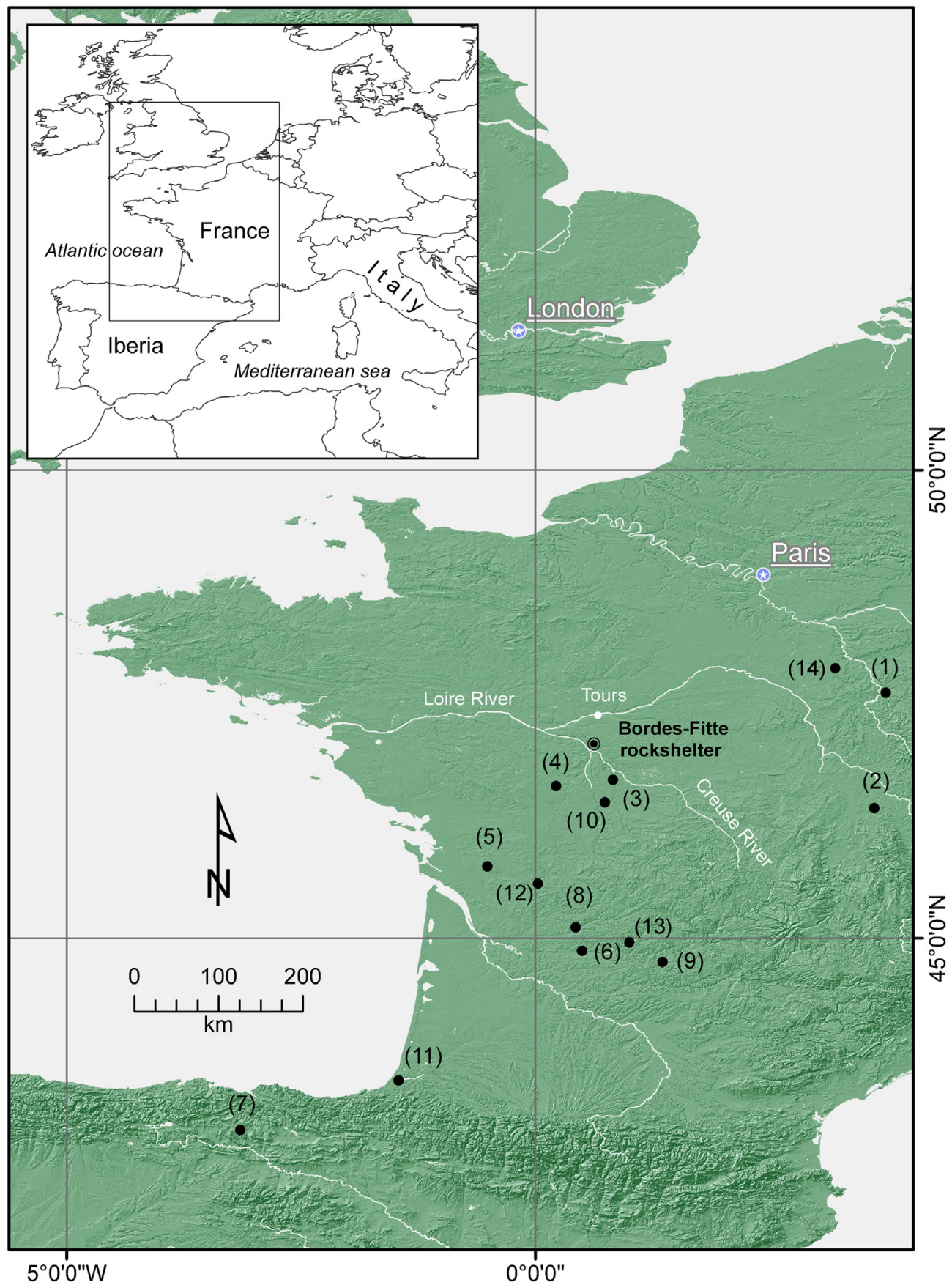

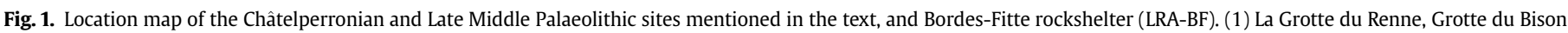

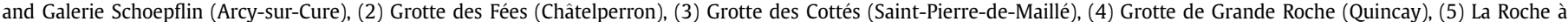

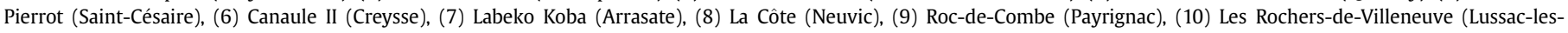
Châteaux), (11) Le Basté (Saint Pierre d'Irube), (12) La Quina (Gardes-Pontaroux), (13) Le Moustier (Peyzac-le-Moustier), (14) Les Bossats (Ormesson). 
inter-bedded rockshelters and caves, which are exposed to the south and southwest along a quarried escarpment at the right margin of the valley, at the southern limit of the Touraine region (Aubry et al., 2012). It is midway between La Roche à Pierrot (SaintCésaire) and the Grotte du Renne (Arcy), which are two key MUP occupational sequences that continue to stimulate heated debate (Fig. 1, Higham et al., 2010, 2014; Hublin et al., 2012).

Since 2007, excavations have been carried out at several locations along the $\sim 300 \mathrm{~m}$ long cliff where large collapsed roofs and walls slabs of compact calcarenite and/or silicified have preserved siliciclastic deposits containing Middle Palaeolithic (MP) and EUP remains (Aubry et al., 2012, Fig. 2). The analysis of the difference in bleaching rates of quartz and feldspar luminescence signals indicates that quartz and feldspar grains of these deposits are wellbleached and ages obtained by luminescence are coherent with ${ }^{14} \mathrm{C}$ measurements (Buylaert et al., 2012; Murray et al., 2012).

The data presented in this article concern only the Bordes-Fitte rockshelter (LRA-BF), taking into account archaeological data concerning level $\mathrm{C}$, rockshelter collapse events and stratigraphical subdivisions of the level D established in recent excavations (years
2012-2013). The results include systematic refitting of lithic remains, micromorphological study, new AMS radiocarbon ages obtained on ultrafiltered bone and tooth gelatine, and quartz data from Aubry et al. (2012) which were combined with additional measurements (Thomsen et al., submitted for publication). These data have allowed for the creation of a refined timeline for anthropogenic and non-anthropogenic processes that occurred at the time of the Neanderthal to Anatomically Modern Human transition.

\section{Material and methods}

Considering the two main problems defined above (integrity of geoarchaeological context and dating methods) to explain the difficulty in defining a reliable timeline for the changes through the MUP transition, our approach relies on the reconstruction of the Bordes-Fitte rockshelter site formation processes and to establish a more accurate timescale, correlating AMS ${ }^{14} \mathrm{C}$ and luminescence results.

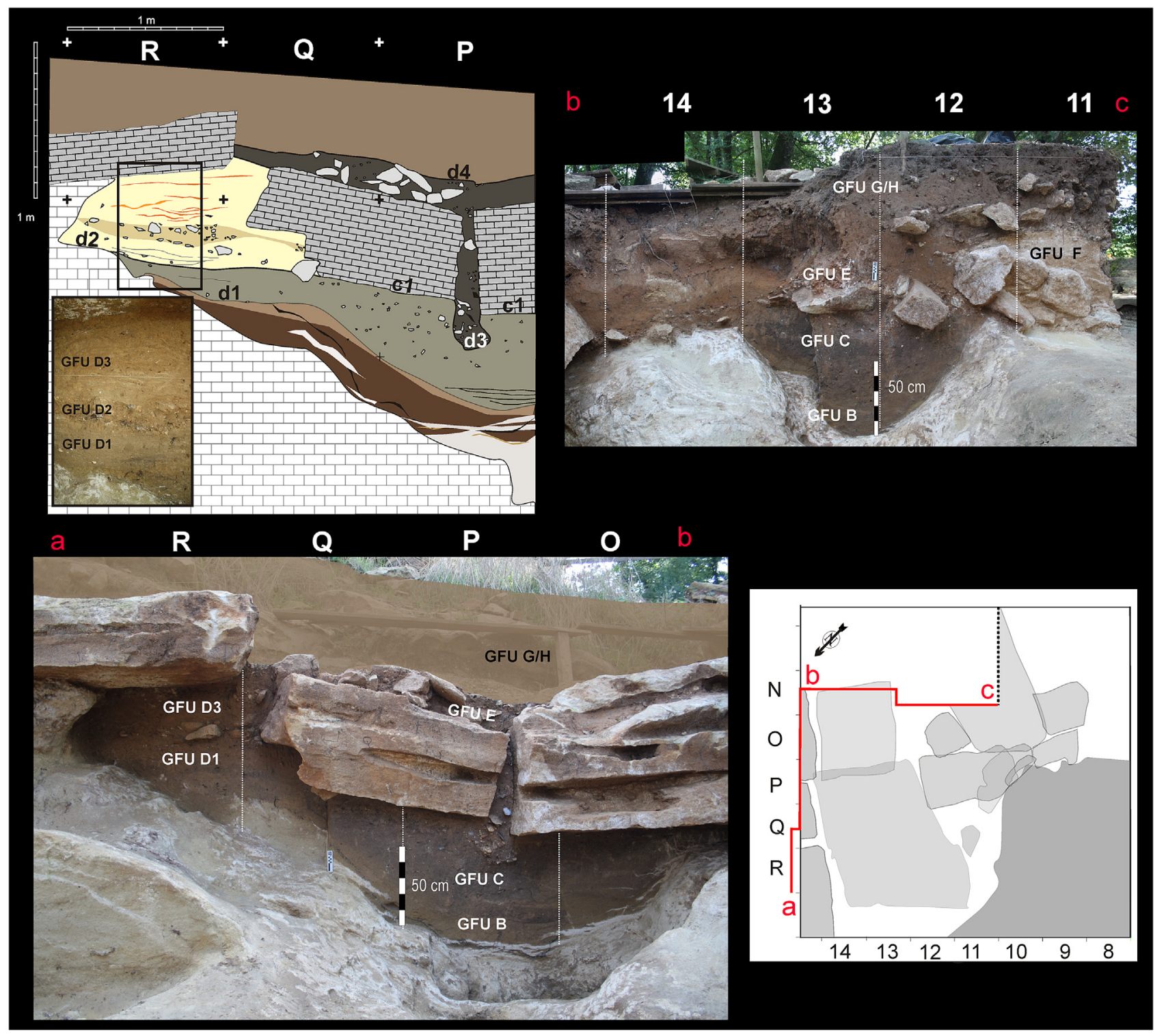

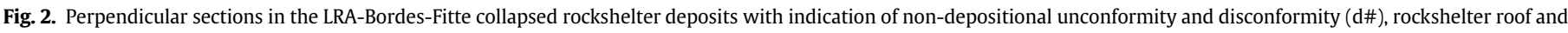
wall collapse event (c\#), and Geological Field Unit B to G/H. 


\subsection{Geoarchaeological approach}

The data were collected under a standard geoarchaeological fieldwork approach including: geomorphological and geological study of the site surroundings, description and stratigraphic correlation of the rockshelter siliciclastic infill, sampling for micromorphological analysis and dating. Field work included the systematic description of cross-sections and profiles to reconstruct stratigraphic events, their vertical and lateral variations and archaeological remains analysis. Geoarchaeological field units (GFU) were identified on the basis of lithostratigraphic, pedological and archaeological criteria and used as field categories. The field units were later grouped into geoarchaeological complexes (GC), taking into consideration only major changes in the depositional style, as well as major unconformities that would imply erosional phases (disconformities) or long hiatuses (details in Angelucci, 2002).

The samples for micromorphological observation were collected at the end of the 2008 and 2012 field seasons. The thin section prepared by Thomas Beckmann Laboratory (Germany) and the EPOC-UMR 5805 Laboratory (France), were observed under a polarizing Stereo-microscope (Nikon) with magnifications between $20 \times$ and $140 \times$ using plane-polarized light (PPL) and crosspolarized light (XPL). Description of the thin sections follows the guidelines proposed by Bullock et al. (1985), Stoops et al. (2010) and Stoops (2003), with additions from Courty et al. (1989) and Goldberg and Macphail (2006).

The field and laboratory sediment's descriptions were made using a comprehensive form addressing the sedimentary, pedogenic and anthropogenic characteristics of the deposits (FAO-Isric 1990; Goldberg and Macphail, 2006; Keeley and Macphail, 1981) to collect the data necessary to assess the site's formation processes.

\subsection{Analysis of lithic industries}

The lithic assemblages were systematically studied for weathering and displacement damage, documenting the breaking, edge and surface abrasion, and the degree of patination. The origin of the raw material was determined by a macroscopical comparison with hand samples collected in the different geological formations of the Creuse and Cher River basins (Aubry, 1991), and the characterization of non-local flint was complemented by a binocular examination of the micro-texture and of the fossil content. The lithic remains were studied using a typo-technological approach, in order to assess reduction sequences and to define retouched tool types (Boëda, 1993, 1994; Dibble and Bar-Yosef, 1995; Pelegrin, 1995), distinguish coherent assemblages, and reconstruct sedimentary dynamic and post-depositional processes considering spatial analysis, systematic refitting (Hofman and Enloe, 1992; Villa, 1982), stratigraphical relationship and three-dimensional plotting using ArcScene 10.

\subsection{Radiometric dating}

The chronological data were obtained by Accelerator Mass Spectrometry (AMS) ${ }^{14} \mathrm{C}$ and Optically Stimulated Luminescence (OSL) multi-grain dating, the latter using quartz and feldspar. Several small fragments of wood charcoal were found in the GFU C, but dating at the Oxford Laboratory failed due to low yield. Thus, all of the samples submitted for radiocarbon dating were of compact mammal bone or tooth identified to species level by Laure Fontana The Beta Analytic protocol of bone pretreatment is collagen extraction with alkali applying the Longin method (Longin, 1971). The bone samples dated at the Lyon and Oxford Radiocarbon
Accelerator Unit (ORAU) were based on chemical pretreatment, target preparation and AMS measurement procedures outlined in previous publications (Higham et al., 2006; Brock et al., 2010).

For the luminescence multi-grain dating, purified quartz and Krich feldspar grains $(180-250 \mu \mathrm{m})$ were extracted from the sediment in the usual manner (Aitken, 1985, 1998). The dose in quartz was measured using a double SAR procedure (Murray and Wintle, 2000; Banerjee et al., 2001) employing infrared (IR, $870 \pm 40 \mathrm{~nm}$ ) stimulation prior to blue $(470 \pm 30 \mathrm{~nm})$ stimulation (both at $125^{\circ} \mathrm{C}$ for $40 \mathrm{~s}$ ) and detection in the UV (Hoya U-340). Thermal treatment used a preheat of $260^{\circ} \mathrm{C}$ for $10 \mathrm{~s}$, a cutheat of $220^{\circ} \mathrm{C}$ and an elevated temperature $\left(280^{\circ} \mathrm{C}\right) 40 \mathrm{~s}$ blue light stimulation after every SAR cycle (Murray and Wintle, 2003). Individual aliquots $(\sim 5 \mathrm{~mm}$ diameter) consisted of a monolayers of grains mounted on stainless steel cups. The usual laboratory tests were undertaken to confirm the appropriateness of the protocol (e.g. recycling, IR depletion ratio, recuperation, dose recovery). The initial $0.5 \mathrm{~s}$ of the signal minus an early background (interval $0.5 \mathrm{~s}-1.0 \mathrm{~s}$ ) was used for all quartz calculations. The dose in feldspar was measured using IR stimulation and detection in a blue-violet window (Schott BG39/ Corning7-59 filters) with $2 \mathrm{~mm}$ diameter grain monolayers in stainless steel cups. A post-IR IR SAR protocol (Thomsen et al., 2008; Buylaert et al., 2012; Thiel et al., 2011) was used with a $60 \mathrm{~s} 320^{\circ} \mathrm{C}$ preheat, first IR stimulation at $50{ }^{\circ} \mathrm{C}(200 \mathrm{~s})$ and the second stimulation (200 s) at $290{ }^{\circ} \mathrm{C}$ and a high-temperature $\left(325^{\circ} \mathrm{C}\right)$ IR exposure $(200 \mathrm{~s})$ after each SAR cycle. Thiel et al. (2011), Thomsen et al. (2011) and Buylaert et al. (2012) have shown that this post-IR IR signal is stable - i.e. anomalous fading (Spooner, 1994) is not detectable. Calculations were made using the initial $2 \mathrm{~s}$ of the post-IR IRSL decay curve minus a background derived from the last $50 \mathrm{~s}$.

Dose rates were determined using high-resolution gamma spectrometry (Murray et al., 1987) and the conversion factors of Guérin et al. (2011). For K-feldspar extracts the internal beta dose rate of ${ }^{40} \mathrm{~K}$ was calculated assuming an effective $\mathrm{K}$ concentration of $12.5 \pm 0.5 \%$ (Huntley and Baril, 1997). Additional OSL single-grain measurements for four quartz samples, with doses in the range 60-110 Gy, have revealed that multi-grain analysis gives the most accurate ages (for details see Thomsen et al., submitted for publication) The radiocarbon determinations obtained by the ultrafiltration protocol and luminescence ages were used to construct a model for the Bordes-Fitte rockshelter site using Bayesian software OxCal 4.2 (Bronk Ramsey, 2013), and the INTCAL13 curve (Reimer et al., 2013).

\section{Sedimentary sources and dynamics in the Bordes-Fitte rockshelter}

The exposed bedrock along the Roches d'Abilly cliff face is composed of an Upper Cretaceous (Upper Turonian) lithostratigraphic succession of chalk, calcareous tufa with some nodular chert, sandy marl, and alternating clastic limestone (bio-calcirudite and calcarenite affected by decalcification and silicification) with thin chert bands, topped by compact silicified limestone (Aubry et al., 2012; Médioni et al., 1974). The sedimentary cover includes Eocene cherty mudstone and lacustrine marls and limestone, MioPliocene formations of mudstone units that overlie the Eocene deposits in some locations, and Quaternary alluvial deposits with some quartz and flint pebbles.

During the final episode of the Upper Cretaceous sub-aerial exposure, and throughout Quaternary times, the carbonate bedrock was affected by several weathering processes including dissolution (Laignel et al., 1999), silicification, ferruginization, and freeze-thaw. The dissolution and freeze-thaw mechanisms were responsible for the development of an important secondary 
porosity that resulted in the development of karstic caves and rockshelters, which were subsequently filled by siliciclastic and carbonate sediments (Aubry et al., 2012).

From the geoarchaeological field description of the sediments in the LRA-BF rockshelter (Aubry et al., 2012, Figs. 2 and 3), it is clear that the siliciclastic inputs are related to the lithology of the incised Cenozoic overlying units (through their sub-aerial erosion and alluvial or down-slope transport and redeposition) coupled with weathering of the carbonate bedrock. As indicated by the common presence of quartz grains, the ultimate origin of the siliciclastic fraction is the widespread Mio-Pleistocene detrital units found lying on the Upper Cretaceous bedrock. The clay and silt inputs, however, are probably also derived from the erosion of earlier Eocene units and of pre-existing cave/rockshelter sediments. Chemical weathering cannot be excluded in the formation of part of this fine fraction.

Carbonate rock fragments of various sizes are present throughout the geoarchaeological sequence (Fig. 3). The origin of these rocky carbonate fragments most likely resides in the normal processes of mechanical degradation of the roof and walls of the caves/rockshelters, as indicated by their heterometry and varied shape. However, it cannot be excluded that some of the smallersized carbonate rock fragments (clasts between 2 and $4 \mathrm{~cm}$ in size) were brought into the karstic forms from the outside, or are related to freeze-thaw weathering of roofs and walls near the entrance, followed by rapid short-distance displacement due to water flow. Such hypothesis could be confirmed by the clast's sharp edges morphologies observed during the micromorphological analysis of the GFU D2. Layered coatings of unsorted silts and many silty clay cappings on the upper part of clasts are other indicators of possible freeze-thaw impact, observed in the GFU D2 (Fig. 5 and Table 1). These features, particularly the cappings, are traditionally related with melt water percolation during seasonal surface soil thaw (Van Vliet Lanoë, in Stoops et al., 2010). The water logging resulting of a seasonal soil thaw or another cause not identified, could also explain the partial ground mass collapse of the GFU D1 micro-facies (Fig. 5).

In terms of sedimentary dynamics, the lithostratigraphic sequences are composed of near-surface sedimentary facies with vertical and lateral variations within a context dominated by runoff and gravitational processes. There is evidence for several episodes of sediment slope-wash, alluvial and lacustrine deposits, as well as hiatuses in sediment deposition and main erosional phases (Figs. 3 and 4 and Table 1 ).

After/during the opening of an inter-bedded cave (or already a rockshelter with the entrance at the local hydrographic base level), the carbonate bedrock started to weather (GFU A) where it was not covered by sediments, and perhaps this process continues

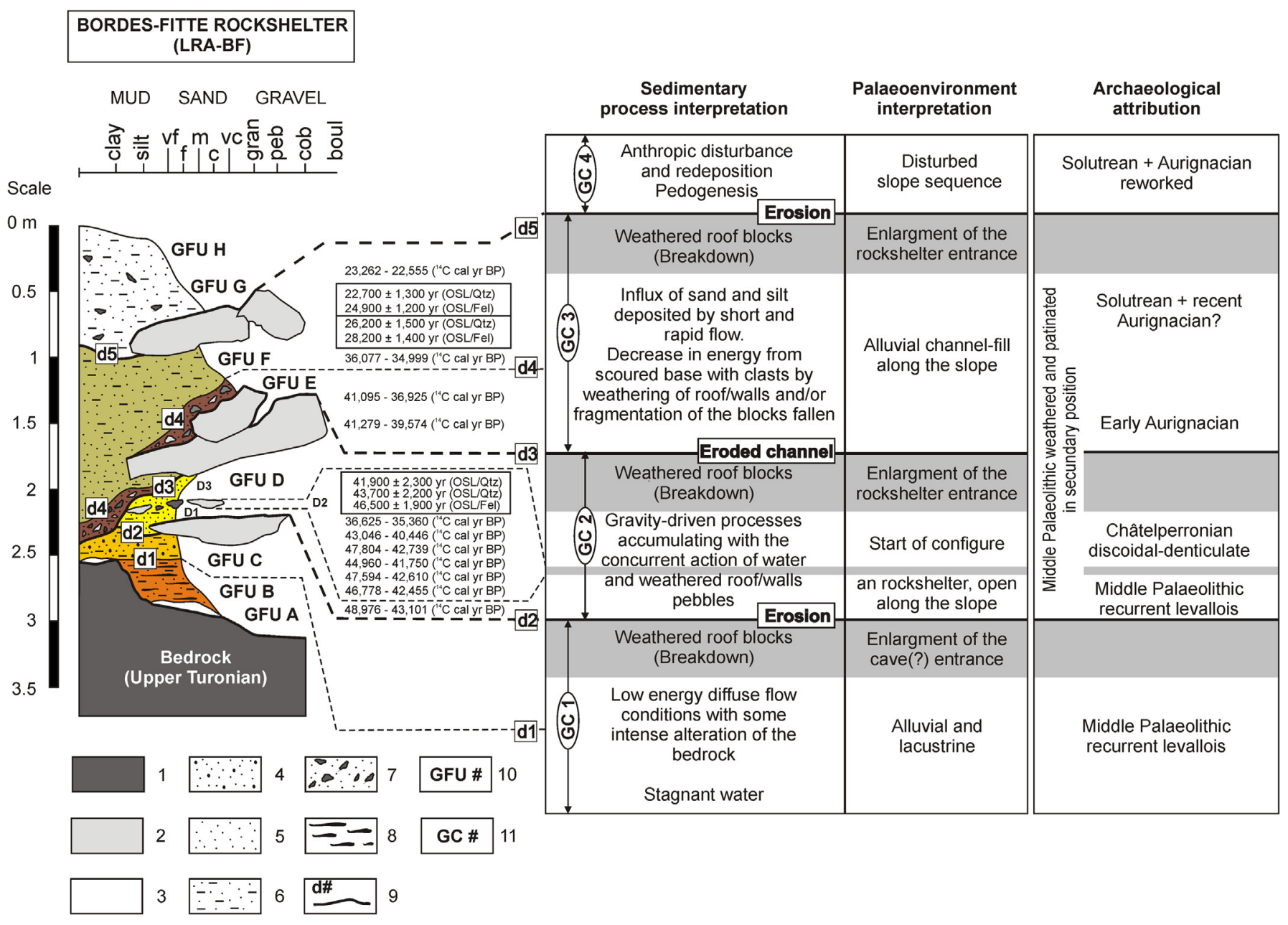

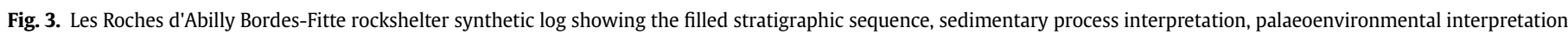

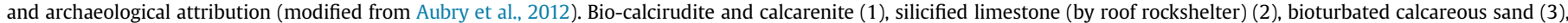

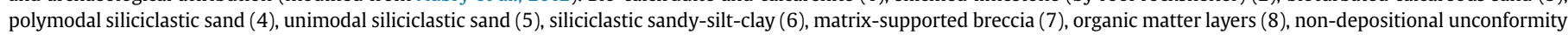
and disconformity (erosional unconformity) (9), geoarchaeological field unit (10), geoarchaeological complex (11). 


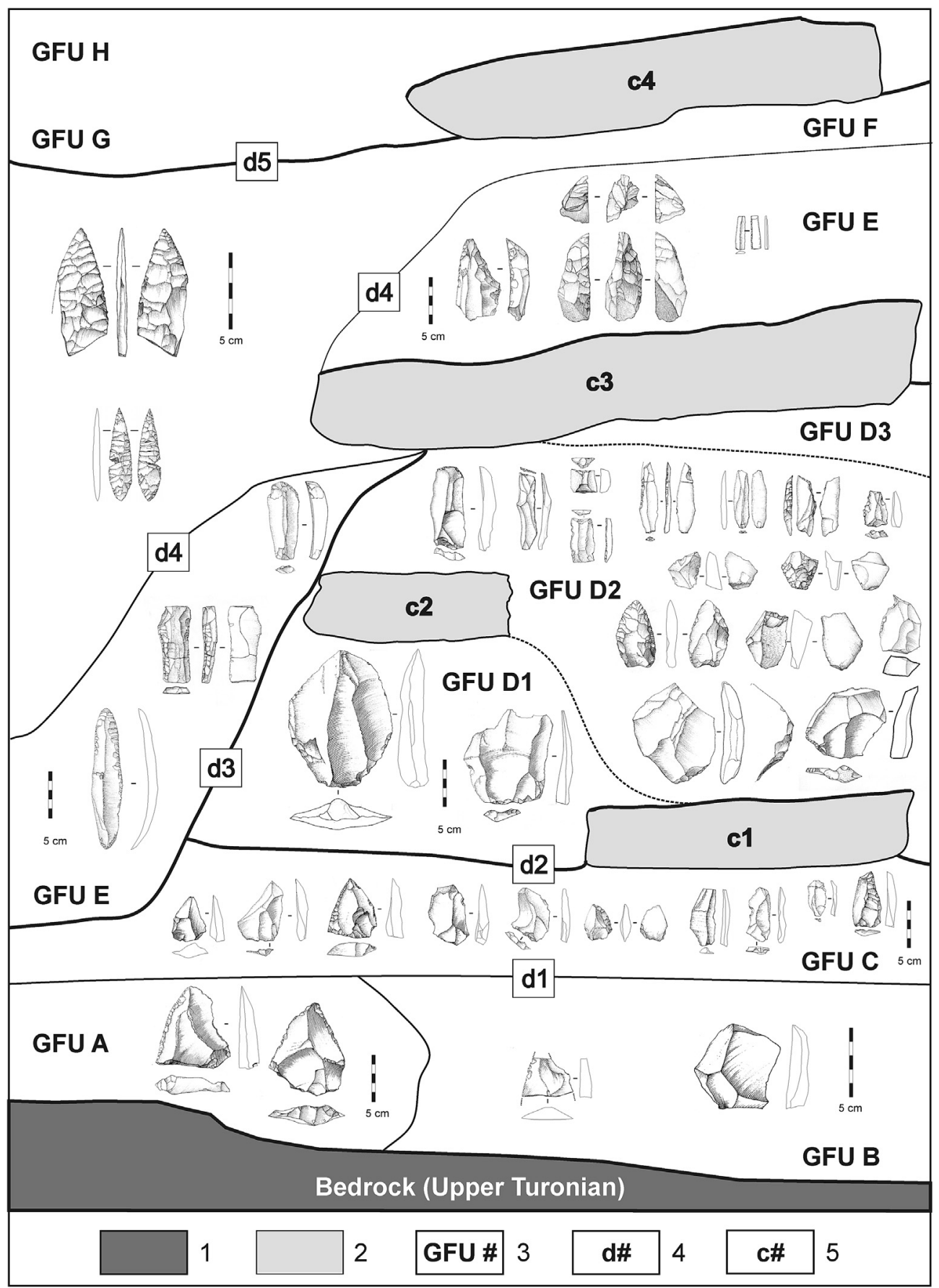

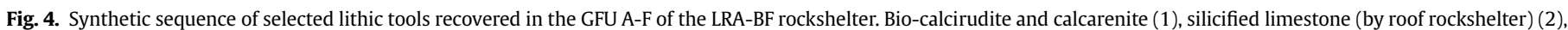
geoarchaeological field unit (3), non-depositional unconformity and disconformity (erosional unconformity) (4), rockshelter roof and wall collapse event (5).

throughout via infilling through cryptocorrosion processes (sensu Nicod, 1994). The initial detrital siliciclastic allochthonous inputs (GFU B and C) are related to an alluvial environment with some lacustrine characteristics, as expressed by grain size, texture and sedimentary features (Table 1 ). These alternate with at least two erosive phases ( $d 1$ and $d 2$ ), coupled with the first important event of cave roof collapse (c1) that results in breakdown calcareous blocks lay on the GFU C (Figs. 2 and 3). This alluvial/lacustrine environment, within a possible context of endokarst fluvial dynamic, is subsequently interrupted by several phases of roof/wall collapses near the cave/rockshelter entrance (GFU D) (i.e. the
Geoarchaeological Complex 2 - GC 2) (Fig. 3). This resulted in the accumulation of pebbles (GFU D2) and large boulders with volumes in the order of cubic meters together with a sandy input (Table 1). These breakdown events could suggest a phase of decompression of the rock mass, which may be the result of climatic factors, seismic events, or a rapid retreat of the cliff related to regional morphodynamic evolution. They indicate the start of a rockshelter opening, able to receive sediments from the slope. Around and under the broken-down roof blocks of the GC 2 complex, a major eroded channel (d3) was filled by an alluvial sequence that developed along the slope (GFU E and F), which was followed by a further 

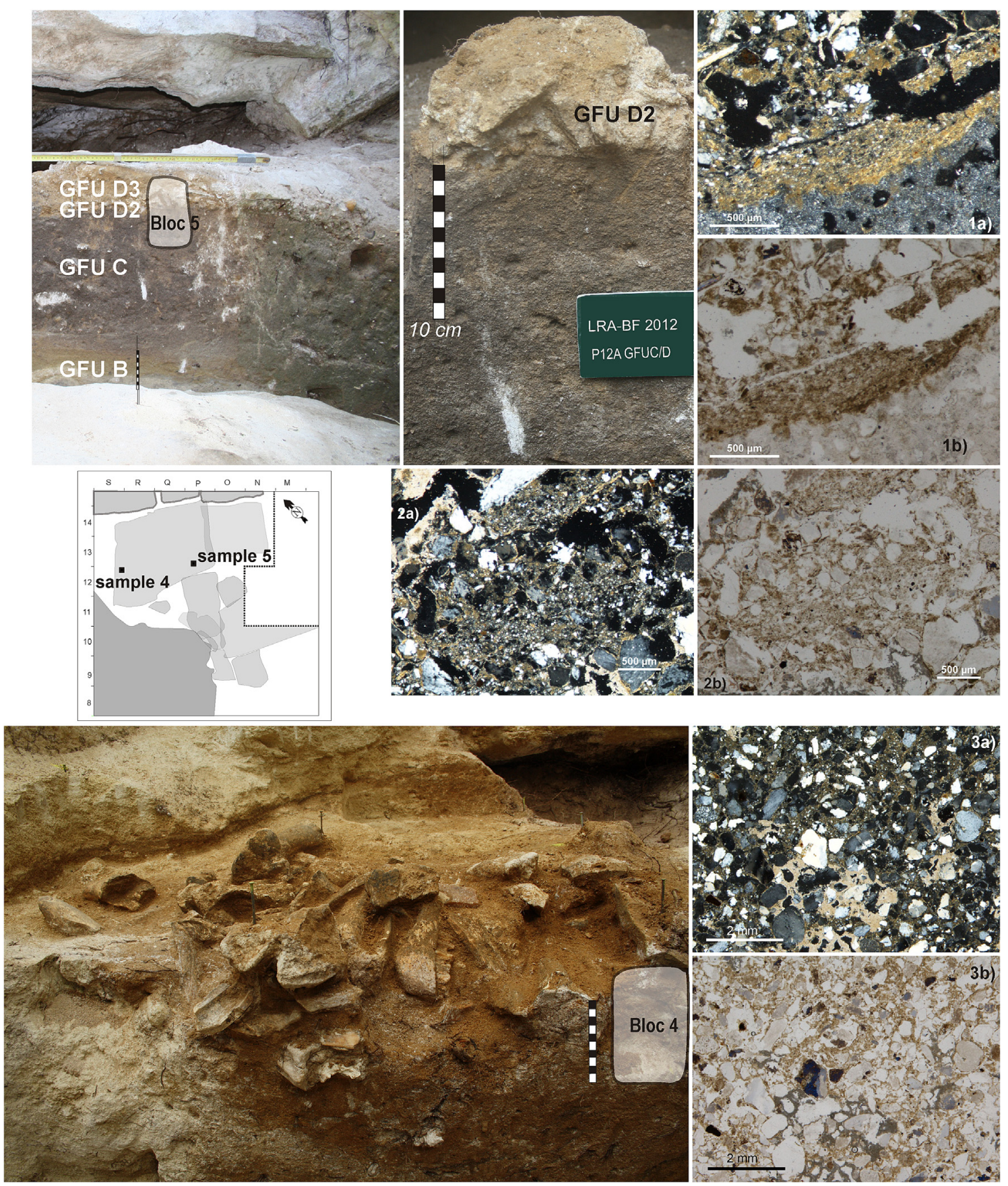

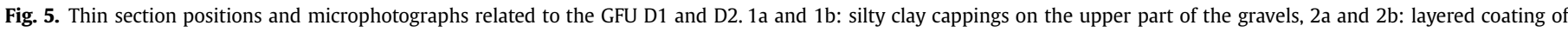

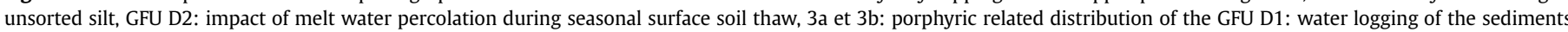
during an episode of seasonal surface soil thaw.

phase of roof breakdown, and consequently the enlargement of the rockshelter entrance (GC 3 complex). Two erosive phases are evident during the filling of the eroded channel (d4) and after the last rockshelter roof collapse event (d5). The dynamics that led to the sedimentation of the upper part of the sequences (GFU G and $\mathrm{H}$ ) (GC 4 complex) are gravity-driven, with some concurrent action of water and inputs from the slope.

\section{Archaeo-stratigraphic and technological evidences}

The GFU A consists of in situ cryptocorrosion of the Turonian bedrock, which has occurred throughout the formation of the entire sequence, beginning prior to the deposition of the GFU B and up through the deposition of the GFU F (Fig. 3 and Table 1). The lithic assemblage recovered in the GFU A deposit, spatially restricted to the squares $\mathrm{N} 9$ and 010 , where GFU B is absent, has yielded a small lithic assemblage (63 pieces), but some pieces are technologically diagnostic. It contains 3 large flakes obtained from large recurrent centripetal or preferential Levallois cores (Boëda, 1994; Dibble and Bar-Yosef, 1995) that have been transformed into side-scrapers through moderate retouch (Fig. 4).

The lithic assemblage recovered from GFU B is also sparse (59 pieces). Some of the flakes were produced using a recurrent centripetal Levallois scheme (Fig. 4). 
Table 1

Micromorphological characteristics of the Bordes-Fitte rockshelter geoarchaeological field units $\mathrm{F}$ to $\mathrm{B}$, and corresponding geoarchaeological complexes (GC).

\begin{tabular}{|c|c|c|}
\hline GC & $\begin{array}{l}\text { GFU } \\
\text { (LRA-BF) }\end{array}$ & Micromorphological characteristics \\
\hline 3 & $\mathrm{~F}$ & $\begin{array}{l}\text { Basic components are } 90 \% \text { coarse silt and a small proportion } \\
\text { of fine sand. Abundant muscovite may correspond to transported } \\
\text { micaflakes, or remnants of limestone weathering. The } \\
\text { microstructure reveal an apedal material, gefuric and porphyric } \\
\text { fabric, and vesicular porosity elongated with vertical orientation. } \\
\text { Calcitic hypocoatings exists around the vesicular voids. } \\
\text { basic components are } 60 \% \text { fine and medium sand and } 40 \% \text { coarse } \\
\text { sand and gravels. The gravels are bioclastic and silicified } \\
\text { limestone. Muscovite is represented by micaflakes of alluvial } \\
\text { origin. The microstructure reveal an apedal material with } \\
\text { pellicular grain structure or compact grain structure, } \\
\text { and chitonic fabric with silt coatings around grains. Textural } \\
\text { pedofeatures have been observed: lenticular beddings (sorted } \\
\text { grains), silt layer up and medium sand layer down and capping } \\
\text { on the top of free grains (silt and sorted quartz) }\end{array}$ \\
\hline
\end{tabular}

2 D D3 Dark yellowish orange siliciclastic fine-medium sand. Without bioturbation. Wedge geometry. The predominant grains of quartz are angular and subangular with high sphericity and well sorted. The matrix is silt. The lower boundary is clear and regular. Thickness is variable, reaching up to some $40 \mathrm{~cm}$.

D2 Basics components are sandy clay loam. The microstructure reveals a chitonic and gefuric related distribution and a granular and pellicular grain structure. The micromass present a granostriated b-fabric. Chert or flint gravels and stones are presents in the ground mass.Textural pedofeatures have been observed: layered coating of unsorted silt (microphotographies $2 \mathrm{a}$ et $2 \mathrm{~b}$, fig. 5) and silty clay cappings (microphotographies $1 \mathrm{a}$ et $1 \mathrm{~b}$, fig. 5) on the up part of gravels. Secondaries carbonatations are presents (impregnation of the ground mass).

D1 Basic components are sandy clay loam. The microstructure reveals an enaulic (chitonic or porphyric by places ; microphotographies 3a et 3b, fig. 5) related distribution and a granular and pellicular grain structure (compact grains by places). The micromass present a granostriated, a reticulatestriated and a stipple speckled b-fabric. Small fragments of bones ( $2 \mathrm{~mm}$ max.) are abundant in the ground mass, glauconites are presents, secondaries carbonatations also.

Basics components are clayey sands. Sands are heterometric. The microstructure reveal an enaulic, chitonic and by places gefuric and porphyric related distribution and a granular and pellicular grain structure. The micromass present a granostriated, a reticulate-striated and an undifferenciated b-fabrics. Some calcitic coatings exists inter-grains, associated sometimes with root tissues. Any coarse layers (medium and coarse grains, with gravels) have been noticed by places. Two types of untypical peds have been observed: one brown, rounded, with an isotropic or stipple speckled birefringence and small dark particles. The second one is a silty clay loam, leached or washed, with a lenticular or lamellar structure. Basic components are clayey sands with glauconites and carbonate gravels in places. Glauconites are abundants and have differents alteration aspects (the last one could be a clay granule). Sands are heterometric. The microstructure reveal an enaulic and chitonic related distribution and a granular and pellicular grain structure. The micromass present a granostriated and a reticulate striated b-fabric. Some calcitic coatings exists inter-grains, associated sometimes with root tissues.

The GFU C contains a lithic assemblage of 1242 pieces (Table 2), mainly composed of pieces of less than $1 \mathrm{~cm}(56 \%)$, and with a high proportion of fragments produced by fire exposure (15\%). The lithic assemblage produced through a recurrent uni and bidirectional convergent or centripetal recurrent Levallois method (Boëda, 1994; Dibble and Bar-Yosef, 1995), is composed of diversified raw material from regional sources. Cores are rare, at the exception of a blank prepared to be exploited and a recurrent centripetal core. Only ten of the Levallois and non diagnostic blanks are transformed in notches, Mousterian points or convergent side scrapers (Fig. 4, Table 2).

The GFU D lithic assemblage is more numerous (9672 pieces, Table 2). Three sub-layers have been distinguished within the GFU D during 2013 excavation (Fig. 2). Sub-layer D3, corresponding to the top of the deposit (Fig. 2), is almost sterile. Sub-layer D1 was only detected under a large rockshelter roof fragment and at its northern limits (Figs. 2 and 4, Table 1). More than 95\% of the GFU D lithic assemblage was recovered in the sub-layer D2. Surface and edge damage analysis shows that its majority (67.2\%) correspond to rounded, highly patinated, edge-damaged, altered by freeze-thaw non diagnostic flake fragments (Table 2, Fig. 6). A small proportion of this patinated and altered component assemblage (ca. 5\%) is composed of cores and flakes, produced in the framework of Discoidal, recurrent uni and bidirectional and centripetal Levallois methods. Some of these blanks are transformed into single and double scrapers (Fig. 6). This highly weathered lithic assemblage is stratigraphically associated with siliciclastic gravels that originate from the Cenozoic units overlying the site, which is evidenced by the over-representation of $1-5 \mathrm{~cm}$ size fraction (Table 1 ). Test excavations undertook along the Roches d'Abilly cliff have revealed that such altered and technological lithic materials are systematically present in the slope deposits in secondary position. Most of this lithic component does not correspond to an occupation of the rockshelter but has probably been remobilized. A lithic component, presenting the same alteration and technological features, integrating fragments of Mousterian of Acheulean Tradition bifaces, is also present in the GFU E, associated with Aurignacian lithic remains.

The remaining part of the GFU D lithic assemblage is composed of pieces damaged by heating (3.5\%), and of very distinct well preserved, non-patinated, fresh-edged lithic remains (29.3\%). These reveal three different typo-technological components. The first corresponds to Levallois recurrent centripetal and possibly preferential non retouched flakes transformed into single or double sidescrapers (Fig. 7). Several varieties of the local Turonian flint have been used and no core is present. The second (181 pieces) corresponds to flakes produced by a Discoidal reduction scheme (Boëda, 1993; Thiébaut, 2007; Bodu et al., 2013). Blanks were transformed into single, double or convergent side-scrapers, notches and denticulates (Fig. 8). The third component corresponds to a blade reduction sequence (318 pieces). We interpret this as production aimed at obtaining small blades with rectilinear profiles from both prismatic and burin type cores, using soft stone hammers, that corresponds with the manufacture of blanks for Châtelperronian (CP) points, which have been recovered at the site (Figs. 9 and 11). A few of the larger prismatic blades and configuration flakes were retouched into end-scrapers or truncations. The prismatic bidirectional hard hammer removal and flake-core reduction scheme found in the GFU D, and at the bottom of layer GFU E, are very similar to those described for the $\mathrm{CP}$ material from the French sites of Roc-de-Combe, la Côte (Fig. 1, Pelegrin, 1995), Canaule II (Bachellerie, 2011; Bachellerie et al., 2008), Le Basté (Bachellerie, 2011), La Grande Roche (Lévêque et al., 1994; Roussel, 2011), La Grotte du Renne (Bodu, 1990; Connet, 2002; Gouedo, 1990) and in Northern Spain at Labeko Koba (Rios-Garaizara et al., 2012).

Layer GFU E, which corresponds to an alluvial channel-fill along the slope (Figs. 2-4), contains both soft hammer-struck unipolar blade and bladelet on nose, and burin type cores production, transformed into tool types ("strangled" blades, end-scrapers with invasive scalariform retouch, Dufour bladelet of the sub-type Dufour) characteristic of the Aurignacian. The two ${ }^{14} \mathrm{C}$ ages obtained suggest the presence of two distinct Aurignacian occupations of the site (Aubry et al., 2012). Finally, a Solutrean occupation is attested by the presence of bifacial thinning flakes, bifacial 
Table 2

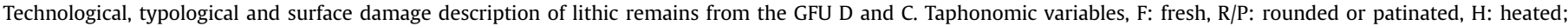

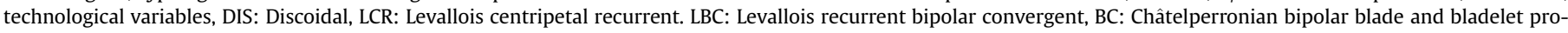
duction, ND: technologically non-diagnostic blanks.

\begin{tabular}{|c|c|c|c|c|c|c|c|c|c|c|c|c|c|c|c|c|}
\hline \multirow{2}{*}{$\frac{\text { Technology }}{\text { Surface damage }}$} & \multicolumn{3}{|l|}{ DIS } & \multicolumn{3}{|c|}{ LRC } & \multicolumn{3}{|c|}{ LBC } & \multicolumn{3}{|l|}{$\mathrm{BC}$} & \multicolumn{3}{|l|}{ ND } & \multirow[t]{2}{*}{ Total } \\
\hline & $\mathrm{F}$ & $\mathrm{R} / \mathrm{P}$ & $\mathrm{H}$ & $\mathrm{F}$ & $\mathrm{R} / \mathrm{P}$ & $\mathrm{H}$ & $\mathrm{F}$ & $\mathrm{R} / \mathrm{P}$ & $\mathrm{H}$ & $\mathrm{F}$ & $\mathrm{R} / \mathrm{P}$ & $\mathrm{H}$ & $\mathrm{F}$ & $\mathrm{R} / \mathrm{P}$ & $\mathrm{H}$ & \\
\hline GFU D total & 181 & 131 & 0 & 21 & 141 & 1 & 0 & 0 & 0 & 318 & 98 & 6 & 2323 & 6127 & 325 & 9672 \\
\hline Single side-scraper & 3 & & & 10 & 2 & & & & & & & & & & & \\
\hline Double side-scraper & 2 & & & 2 & & & & & & & & & & & & \\
\hline Convergent side-scraper & & 1 & & & & & & & & & & & & & & \\
\hline Notch & 5 & 1 & & 1 & & & & & & 4 & & & & & & \\
\hline Denticulate & & & & & & & & & & 1 & & & & & & \\
\hline \multicolumn{17}{|l|}{ Truncation } \\
\hline Truncated blade & & & & & & & & & & 11 & 1 & & & & & \\
\hline End-scraper & & & & & & & & & & 4 & 2 & & & & & \\
\hline Burin & & & & & & & & & & 1 & & & & & & \\
\hline Chatelperronian point & & & & & & & & & & 7 & 1 & & & & & \\
\hline Retouched blade & & & & & & & & & & 10 & & & & & & \\
\hline Retouched flake & & & & 1 & & & & & & & & & & & & \\
\hline Total retouched & 10 & 2 & 0 & 14 & 2 & 0 & & & & 38 & 4 & 0 & 60 & 54 & 0 & 184 \\
\hline Non retouched & 171 & 129 & 0 & 7 & 139 & 1 & & & & 280 & 94 & 6 & 2263 & 6073 & 325 & 9488 \\
\hline GFU C total & 2 & 0 & 0 & 16 & 30 & 2 & 3 & 19 & & 0 & 0 & 0 & 277 & 709 & 184 & 1242 \\
\hline Single side-scraper & & & & & & & & 1 & & & & & & & & \\
\hline Convergent side-scraper & & & & & 1 & & & 1 & & & & & & & & \\
\hline \multicolumn{17}{|l|}{ Double side-scraper } \\
\hline Mousterian point & & & & & 1 & & & 1 & & & & & & & & \\
\hline Notch & & & & 1 & 1 & & & 1 & & & & & & 1 & & \\
\hline Denticulate & & & & & & & & & & & & & & 1 & & \\
\hline Retouched & 0 & 0 & 0 & 1 & 3 & 0 & 0 & 4 & 0 & 0 & 0 & 0 & 0 & 2 & 0 & 10 \\
\hline Non retouched & 2 & 0 & 0 & 15 & 27 & 2 & 3 & 15 & & 0 & 0 & 0 & 277 & 707 & 184 & 1232 \\
\hline
\end{tabular}

preforms and several fragments of laurel-leaves (Fig. 4) recovered in the GFU F, which follows the deposition of a sterile stratified sand deposit, and a collapse of the western portion of the rockshelter (Fig. 3 and Table 1).

\section{Identifying cultural and natural formation processes at the Bordes-Fitte rockshelter}

Faunal remains recovered in the GFU A, B, C and D, primarily result from anthropogenic activities, with some evidence of carnivore and post-depositional modification. In all the faunal assemblages, bison and/or aurochs and horse dominate, followed by red deer and reindeer, wholly rhino and carnivores (Felidae, Hyenidae, Canidae and Ursidae). Attempted refitting between faunal remains fragments of the different GFU has revealed a very low refit ratio (Aubry et al., 2012).

Faunal remains, independently of GFU assignation, present different state of preservation, from chalky white appearance to highly mineralized, and most of it is fragmented. The distribution of faunal remains from GFU C, D (D1 and D2) and E, reveals a direct correlation with the limits of the different rockshelter roof fragments (Fig. 10a), that could explain their differential spatial preservation.

As we have seen before, the fresh lithic remains recovered in the GFU D1 and D2 are composed of distinct typo-technological and surface damage groups (Table 2). The distribution of lithic remains and the stratigraphical position of the rockshelter roof and wall fragments reveal that the Levallois component, exclusive in the GFU D1, is mostly preserved under a large roof fragment (Fig. 10b), corresponding to the $\mathrm{c} 2$ event, and that Discoidal and CP lithic artifacts, recovered in the GFU D2, are distributed around this fragment (Figs. 11 and 12). Therefore, Discoidal and CP assemblages are younger than the collapse event $\mathrm{c} 2$ that occurred after the deposition of GFU D1 and before GFU D2 (Figs. 3 and 4).

Technological diversity in a lithic assemblage recovered from a single litho-stratigraphical unit could be interpreted as a high resolution record of a transitional cultural process (evolution, adaptation, acculturation), post-depositional inter-level mixing (Rigaud, 1996), or the result of a cumulative palimpsest. Based on the assumption that the pre-taphonomic assemblages were originally completely non-overlapping in their typo-technological attributes, the nature and extent of post-depositional inter-level mixing affecting deposits, and their respective archaeological components, can be evaluated using different mathematical methods (Brantingham et al., 2007; Caron et al., 2011). Nevertheless, such analyses are not able to determine if an assemblage results from an accumulative palimpsest (Bailey, 2007; Villa, 1982) nor test the reliability of a "transitional" typo-technological characterization of a lithic assemblages recovered from a specific archaeo-stratigraphic unit.

In order to assess formation processes and examine stratigraphic coherence and potential disturbance of archaeological assemblages, other methods have been developed, such as the study of the orientations of elongated lithic and bone remains within a deposit, known as fabric analysis (Bertran et al., 1997; Lenoble and Bertran, 2004; McPherron, 2005). The method is based on the assumption that patterning in object orientation tends to indicate if deposits have been subject to some sort of post-depositional alteration. Statistical analysis of orientation measurements, compared to actual re-orientation pattern observed in slopes, are used to reconstruct natural processes responsible for the formation of deposits containing archaeological remains (i.e. rock-falls, solifluction, debris flows, dry grain flows, frost-coated clast flows and run-offs). Calculation derived from the position of elongated flint and bones artifacts in both GFU E and F of LRA-BF have generated 

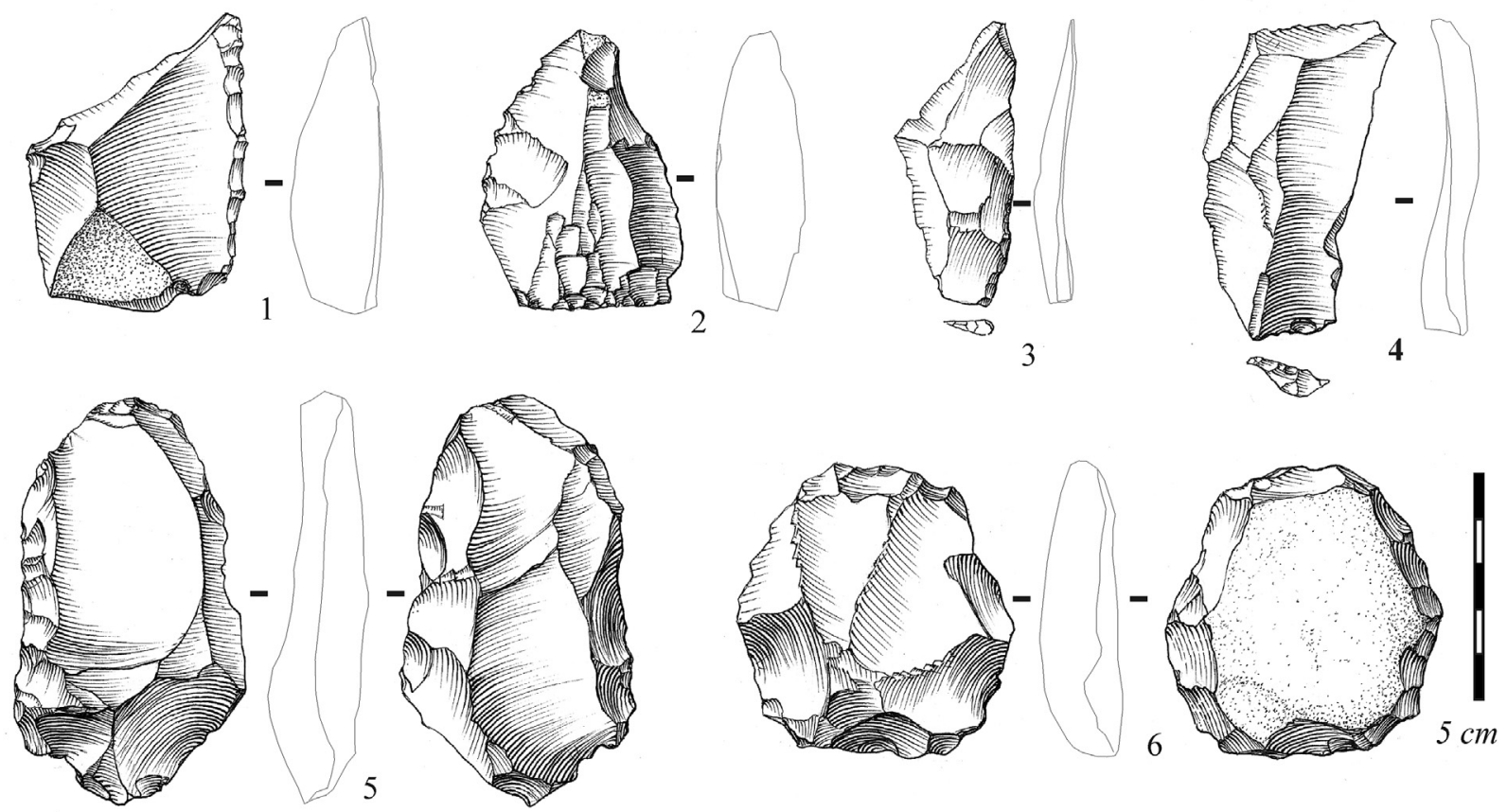

S R

Q P

O

$\mathrm{N}$

M
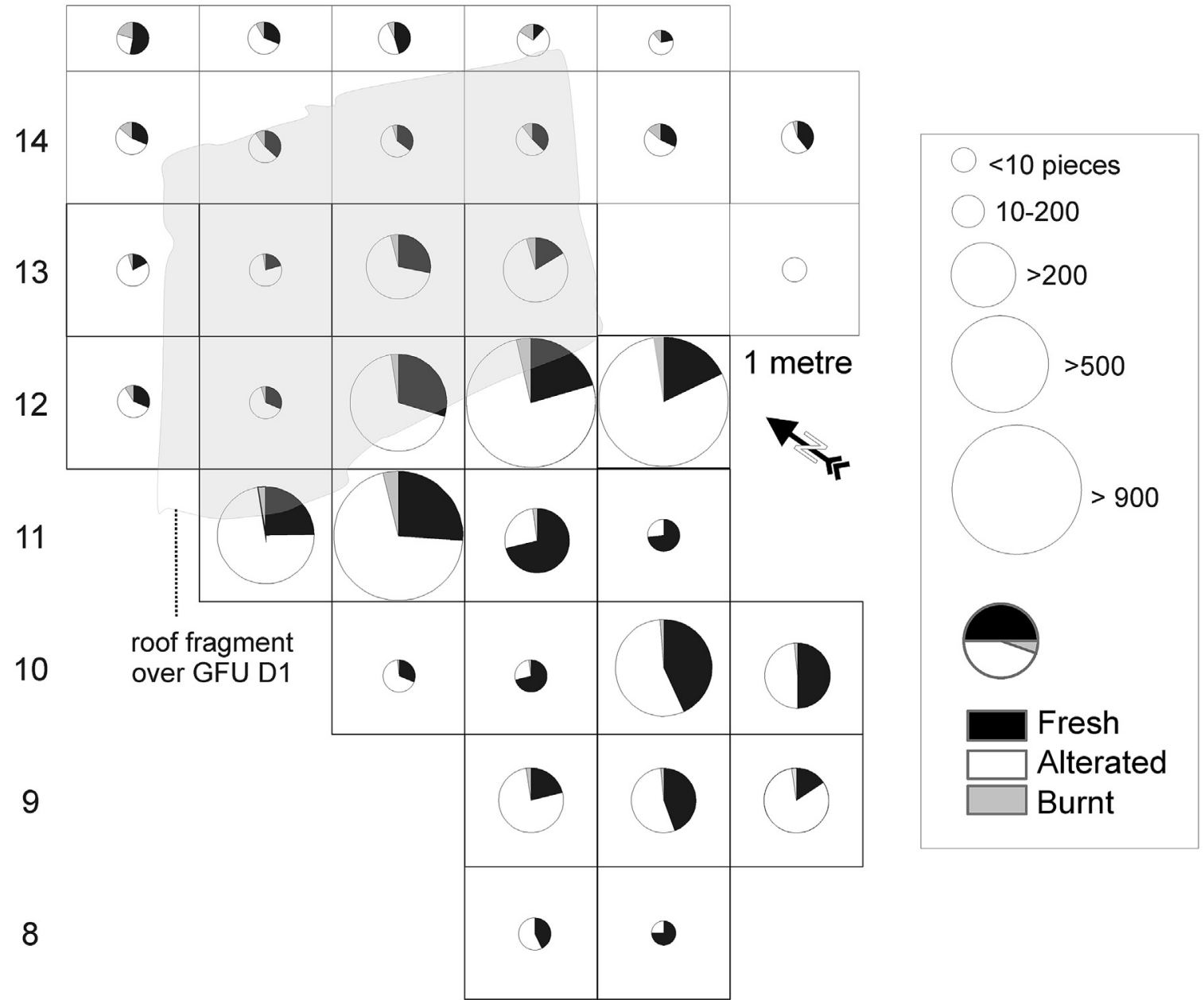

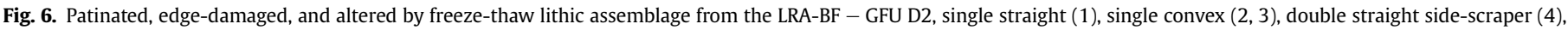

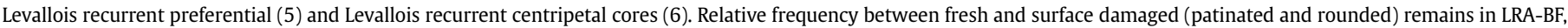
GFU D. 

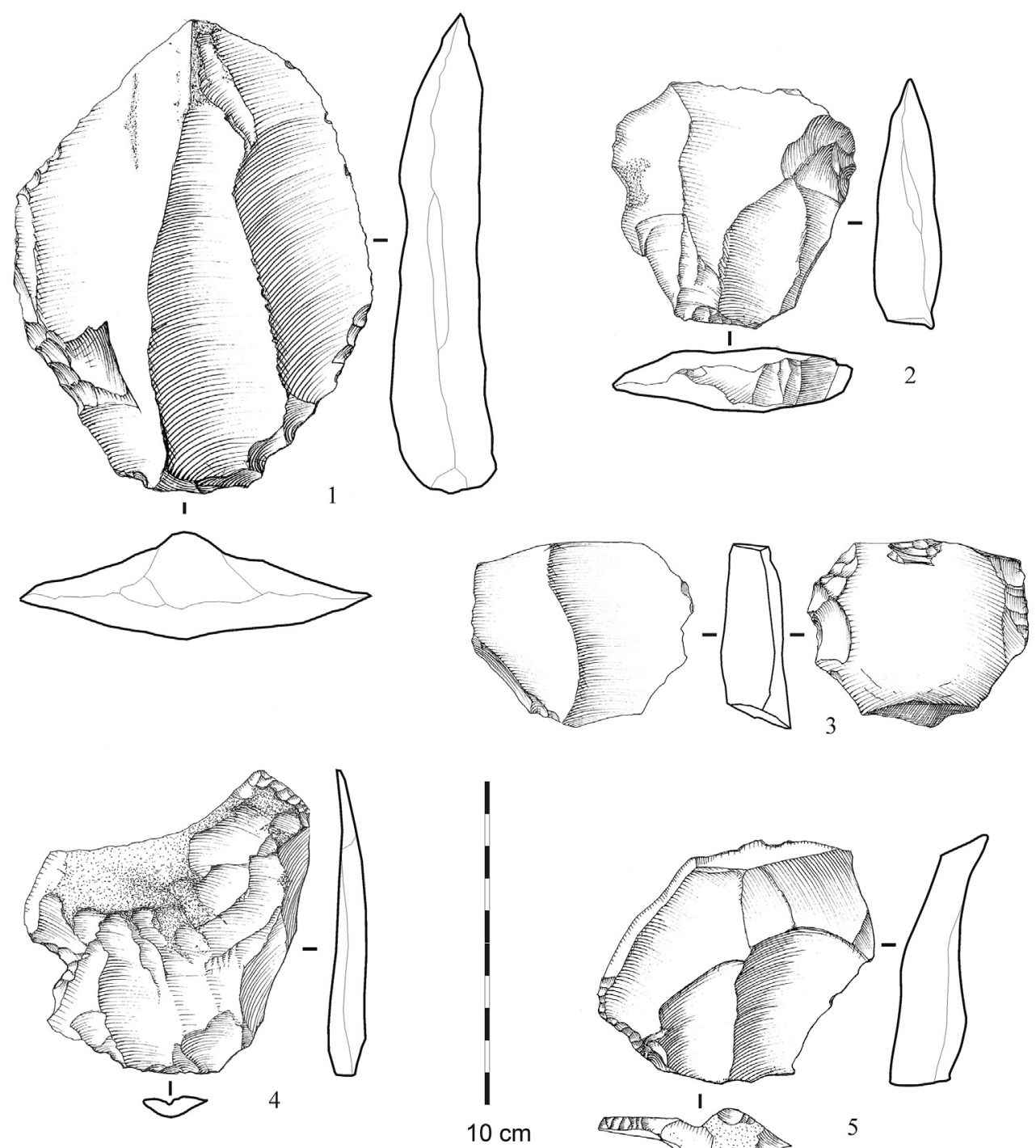

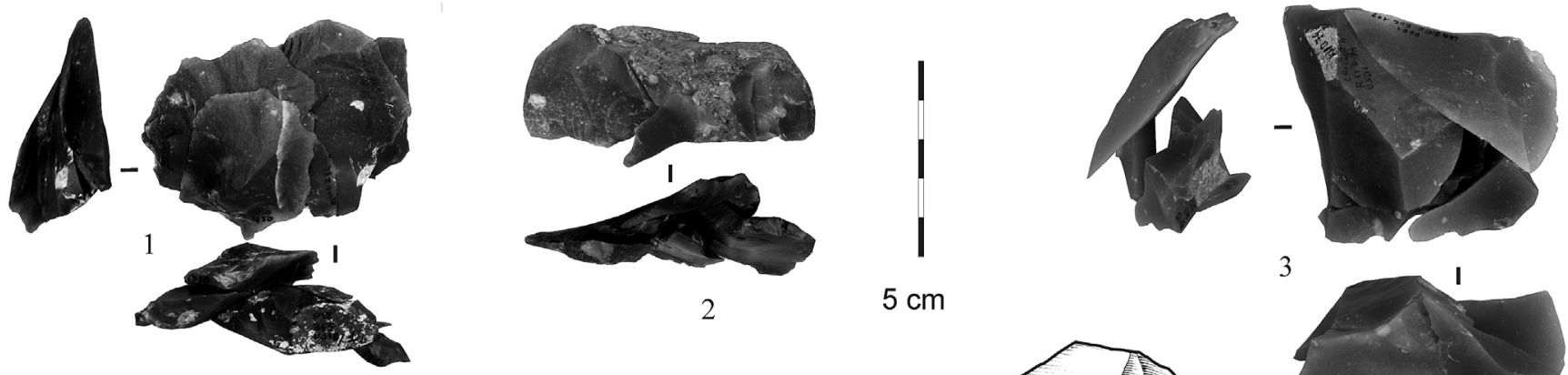

2

$5 \mathrm{~cm}$

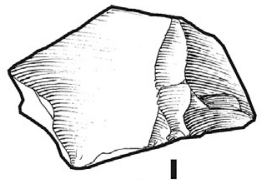

3
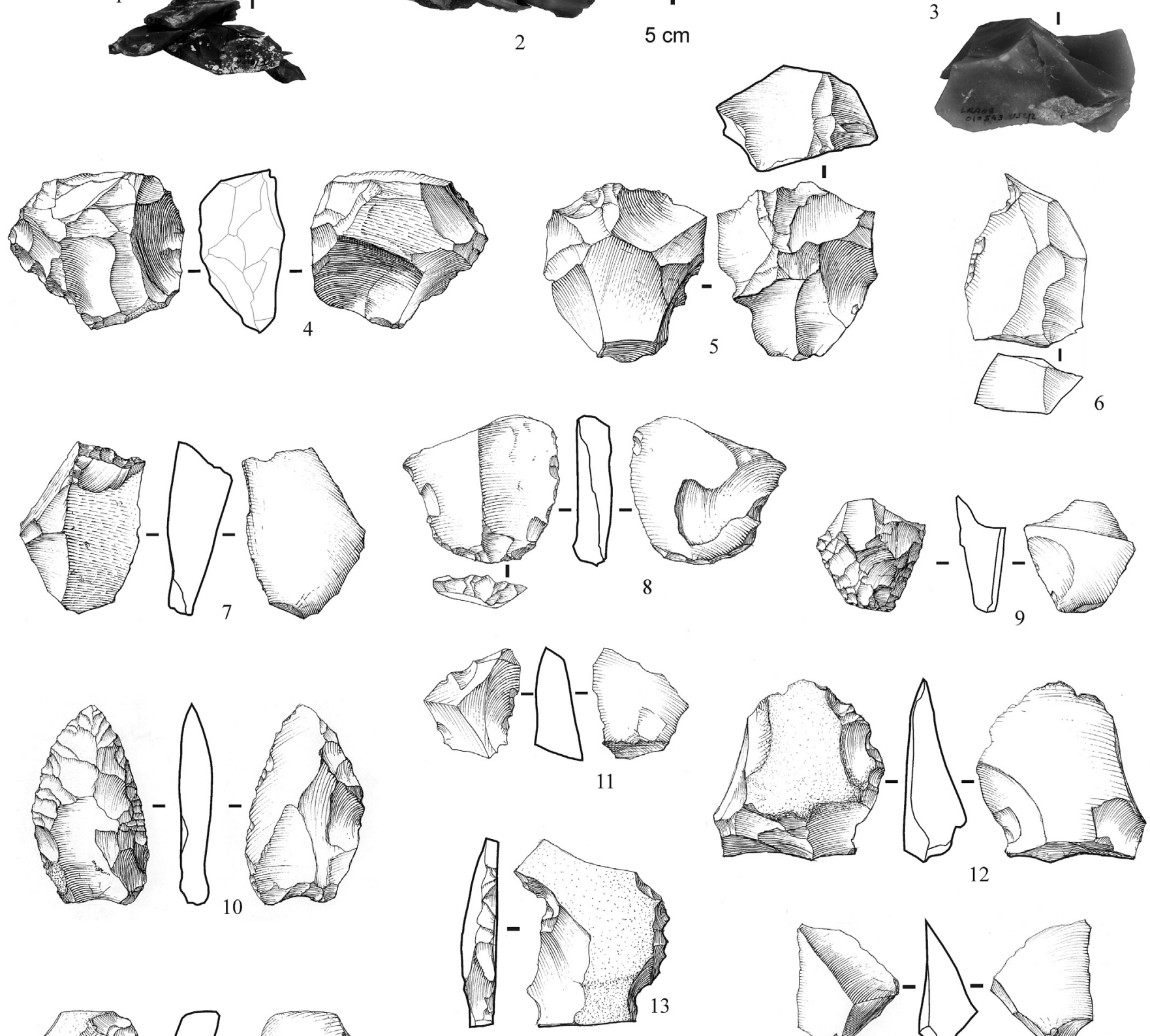

12

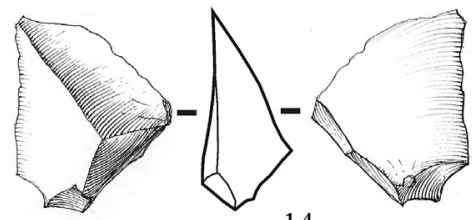

14
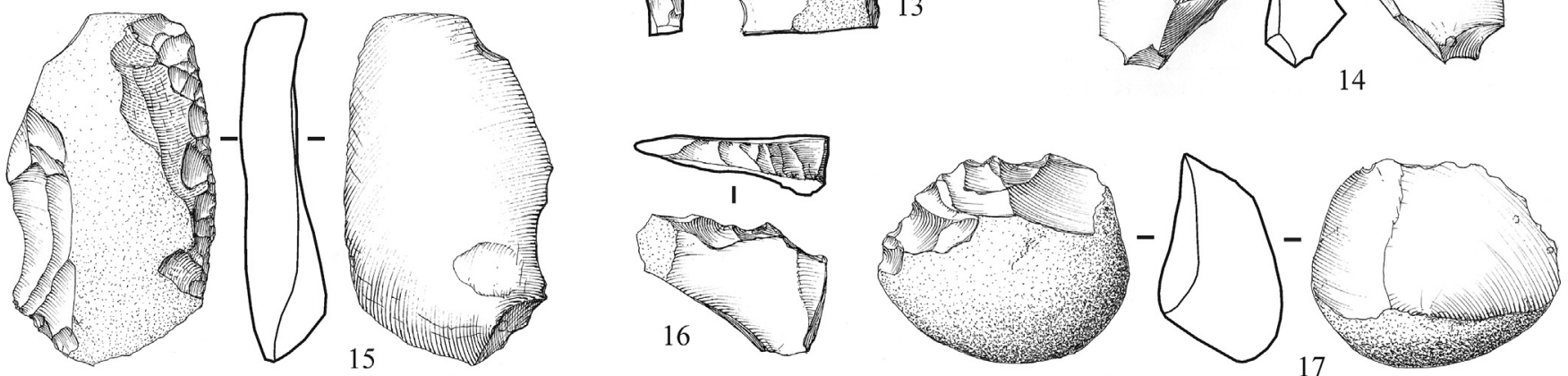

Fig. 8. Well preserved, non-patinated, fresh-edged and surface lithic assemblage from the LRA-BF, GFU D2. Discoidal flake removal refitted sequences (1-3), Discoidal reduction scheme core $(4,5)$, pseudo-Levallois point $(14)$, single convex side-scrapers $(15,17)$, double convex, convex-concave side-scrapers $(8,9,12,13)$, convex convergent with bifacial retouch side-scraper (10), truncation (16), notch (6) and denticulate (11). 

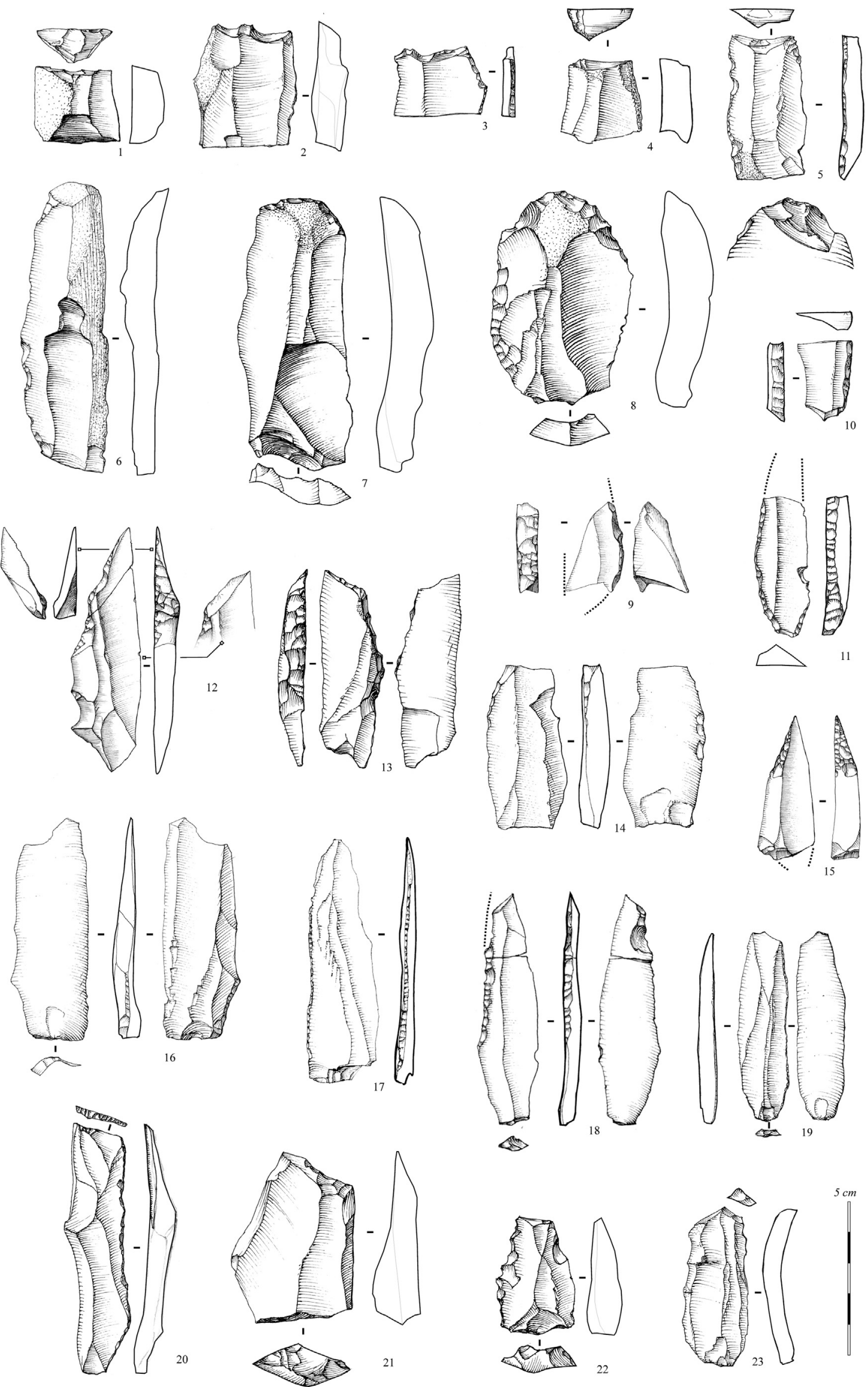


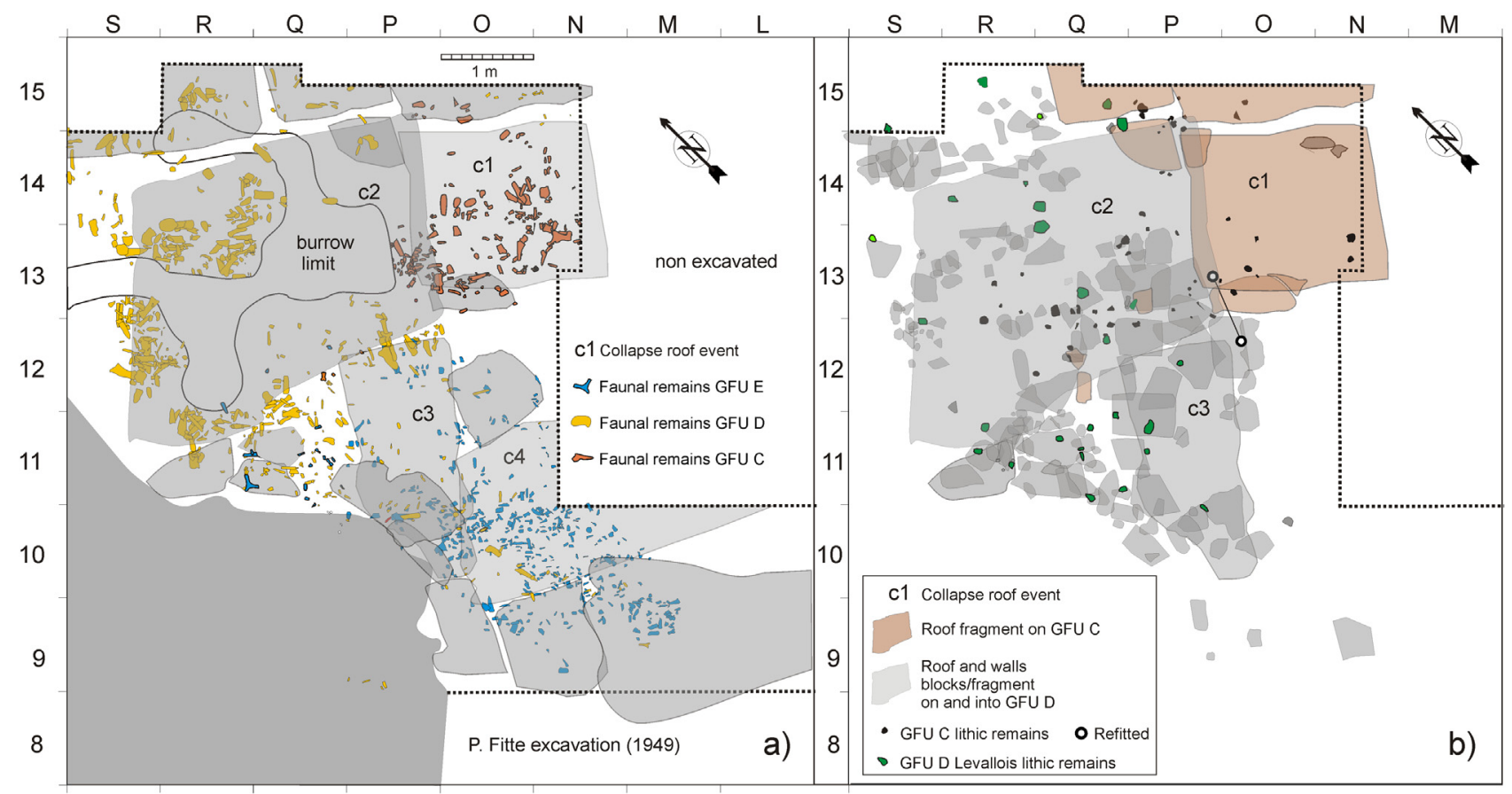

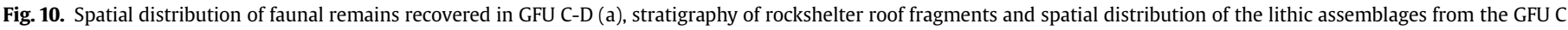
and $\mathrm{D}(\mathrm{b})$.

The study of the patinated and altered lithic assemblage of the Bordes-Fitte rockshelter's GFU D2 reveals that it is mostly located around the southern limit of a large roof fragment (Fig. 6). This component is therefore related with an increase of slope dynamics during the deposition of the GFU D2, after the roof collapse event c2 (Table 1). Such technological and surface damaged assemblage is also present in GFU E, and in all the Roches d'Abilly slope deposits (Aubry et al., 2012).

Refitting is another essential tool in assessing the integrity of archaeological assemblages (Hofman and Enloe, 1992; Discamps et al., 2012). In an attempt to alleviate the doubts concerning the integrity and homogeneity of the Ejop sup level at la Roche à Pierrot (Backer, 1993), Morin et al. (2005) carried out systematic bone refits between 8 stratigraphic faunal assemblages. In his Doctoral thesis, Bachellerie (2011) presents the results of a taphonomical and technological analysis that incorporates data from systematic refitting between fragmented flakes and blades of the Roche à Pierrot Ejop level. Bachellerie's study confirms that the Ejop inf and Ejop sup are different levels, and interprets the differential preservation, orientation, low rate of refitting (4\%), and the diversity of the reduction sequences as the result of a cumulative palimpsest of Discoidal/Denticulate, Levallois/large side-scraper, and CP blade occupations. The refitting approach developed by Bodu (1990) has established the relationship between 200 pieces of the Grotte du Renne level X. Hublin et al. (2012) have recently published the spatial distribution of some of these refits in the sublayers of level $\mathrm{X}$. The authors state that "the discovery of some refits between $\mathrm{CP}$ layers and sublayers led us to group the CP into only two chronostratigraphic units", and that "considering documented human and animal activities in the site during these two periods, considering the challenging situation of recognizing occupation floors during excavation on large surfaces of a cave deposit, and considering the limits of radiocarbon precision in this time period, further refinements in the chronostratigraphy presented here are unlikely".
Refitting has been systematically applied to LRA-BF lithic assemblages independently of their stratigraphic provenience. The lithic assemblage recovered from GFU C is essentially composed of pieces less than $1 \mathrm{~cm}$ (56\%) (Table 2). It is made from various local flint sources and the rarity of cores corroborate what lithic industry was probably not produced on the excavated area. A unique refit was found within this level (Fig. 10b) which corresponds to a postdepositional fracture.

Refits are completely absent between the highly patinated and altered lithic assemblage of the GFU D, which are in secondary position due to the increase of slope dynamics after the rockshelter collapse event $\mathrm{c} 2$. For a different reason, the same applies to Levallois large flakes of the GFU D1 (Fig. 10b), which were probably not produced on the excavated area.

The Middle Palaeolithic Discoidal remains of the GFU D2 are made of several varieties of Upper Turonian flints available locally, some of which are represented by a single piece. A smaller number of Lower Turonian flint objects (20 pieces) attests to procurement from a distance of ca. $60 \mathrm{~km}$. The low refit ratio for this technological assemblage (Fig. 11) could be explained by the discard of flakes or tools produced outside the rockshelter or post-depositional disturbance. These refits show a re-orientation pattern that could be the result of run-off processes in two main directions (circa N/S for the longest axis and $\mathrm{E} / \mathrm{W}$ for the shortest) that correspond to the main dip (Figs. 11 and 13 ).

CP blade production is only made on Upper Turonian flint collected from Upper Turonian outcrop and fluvial terraces local sources. Refits indicate the presence of elements corresponding to all production phases for $\mathrm{CP}$ point production, mostly distributed by the southern limits of the large roof fragment (Fig. 11) corresponding to the collapse event c2 (Fig. 4). The pieces recovered at the northern limit (Fig. 11) correspond to the Châtelperronian points and end-scrapers blanks missing from the refit sequences. The $\mathrm{CP}$ production sequence yielded a high 

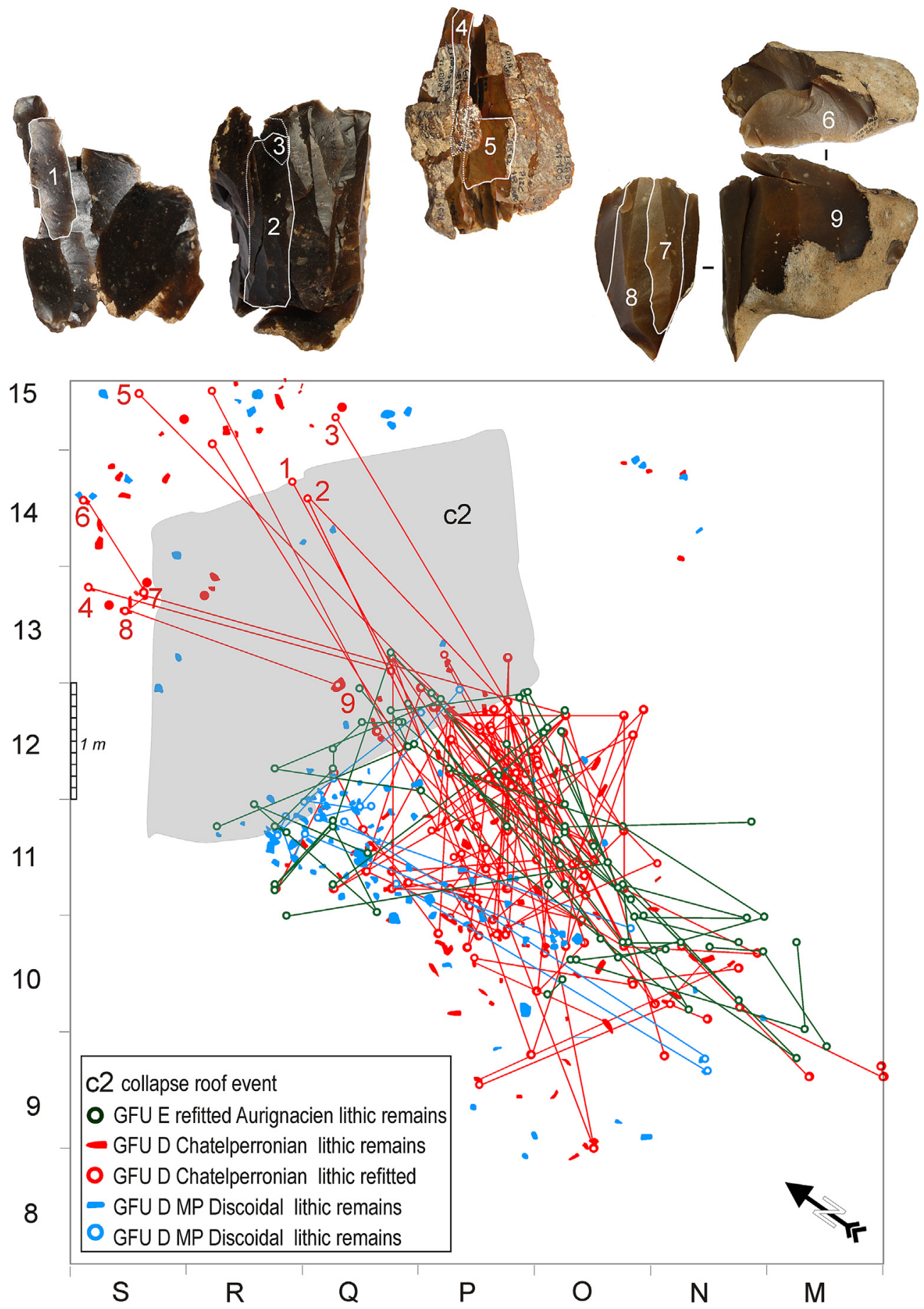

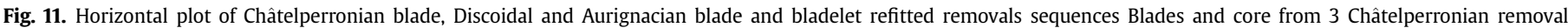
sequences.

refit ratio, and most of the non refitted pieces are composed of fragment less than $1 \mathrm{~cm}$. The refit rate (between $17 \%$ and $56 \%$ of the total pieces from 5 characteristic Turonian flint categories) is similar to the obtained for the refitting of experimental flake reduction sequences (Laughlin and Kelly, 2010), suggesting a low magnitude of post-depositional disturbance for the $\mathrm{CP}$ remains.

However, the distribution and refits of $\mathrm{CP}$ remains indicate that these remains were also affected by non-anthropogenic reorientations (NNE-SSW with ENE-WSW and NW-SE secondary directions). The main direction corresponds to the orientation of refitted pieces recovered at the top of layer GFU D and integrated later at the bottom of the GFU E. These are spatially limited to the area not covered by the rockshelter roof fragments, and correspond to the pattern of orientation in the refits of Aurignacian lithic artifacts recovered in layer GFU E (Figs. 11 and 13). This result is consistent with the notion that, in areas not sealed by roof collapse, finds from the GFU D2 were removed during an erosional event (d3, Fig. 3 and Table 1), preceding the deposition of the GFU E, along an erosion channel that follows the limits of the fragmented roof 


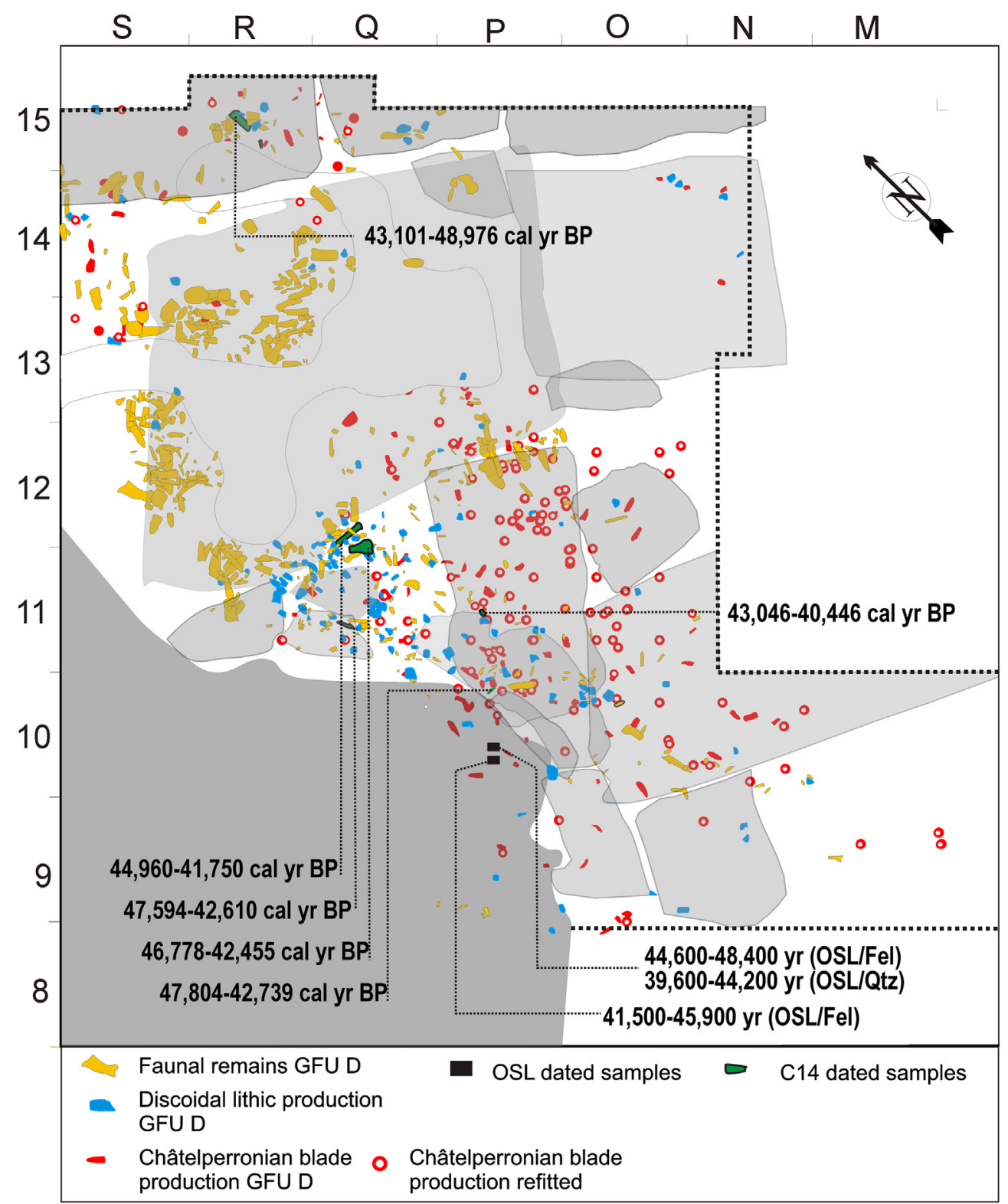

Fig. 12. Distribution of Discoidal and $\mathrm{CP}$ lithic remains and refitting as compared to faunal remains and bone/tooth dated by ${ }^{14} \mathrm{C}$ in the $\mathrm{GFU} \mathrm{D}$.

blocks. The secondary directions correspond to the inclination of the GFU D and to a run-off process that took place prior to the collapse event c3 (Fig. 4).

Vertical plot of the techno-typological categories defined for the lithic assemblages and faunal remains recovered in the GFU D reveals that faunal remains preserved under the largest roof collapsed fragment are stratigraphically associated with the lithic remains obtained by a Levallois chaine opératoire and stratigraphically associated with the GFU D1 under the large rockshelter roof fragment or the bottom of the GFU D2 (Fig. 10). Other faunal remains, at the southern limit of the large roof collapse, are spatially associated with the Discoidal lithic remains and were affected by the same run-off process that lithic remains (Figs. 12 and 13).

The vertical projection of $\mathrm{CP}$ and Discoidal remains indicates that lithic artifacts corresponding to blade production overlie those that relate to Discoidal flake production (Fig. 13).
Thus, at least three human occupations characterized by distinct lithic flake and blade production could be distinguished into the GFU D, sub-layers D1 and D2 (Fig. 4). The first, defined by large recurrent centripetal or preferential Levallois blanks transformed in side scrapers, associated with faunal remains, is preserved under a large roof fragment in the GFU D1, and was affected by a run-off post depositional process around it and integrated in the GFU D2. A subsequent Discoidal occupation is concentrated at the limit of the large roof fragment in squares $\mathrm{Q} /$ $\mathrm{R}-11 / 12$ and separated from the CP occupation by a wall fragment collapse event (Fig. 3).

\section{Timing of Late Middle Paleolithic and Early Upper Paleolithic occupations at the Bordes-Fitte rockshelter}

The (Beta-249595) age of $32,110 \pm 280{ }^{14} \mathrm{C} \mathrm{yr} \mathrm{BP}(36,625-35,360$ [95.4\%] cal yr BP) is the only result clearly incoherent with its stratigraphic position (Fig. 3, Aubry et al., 2012). The hypothesis 

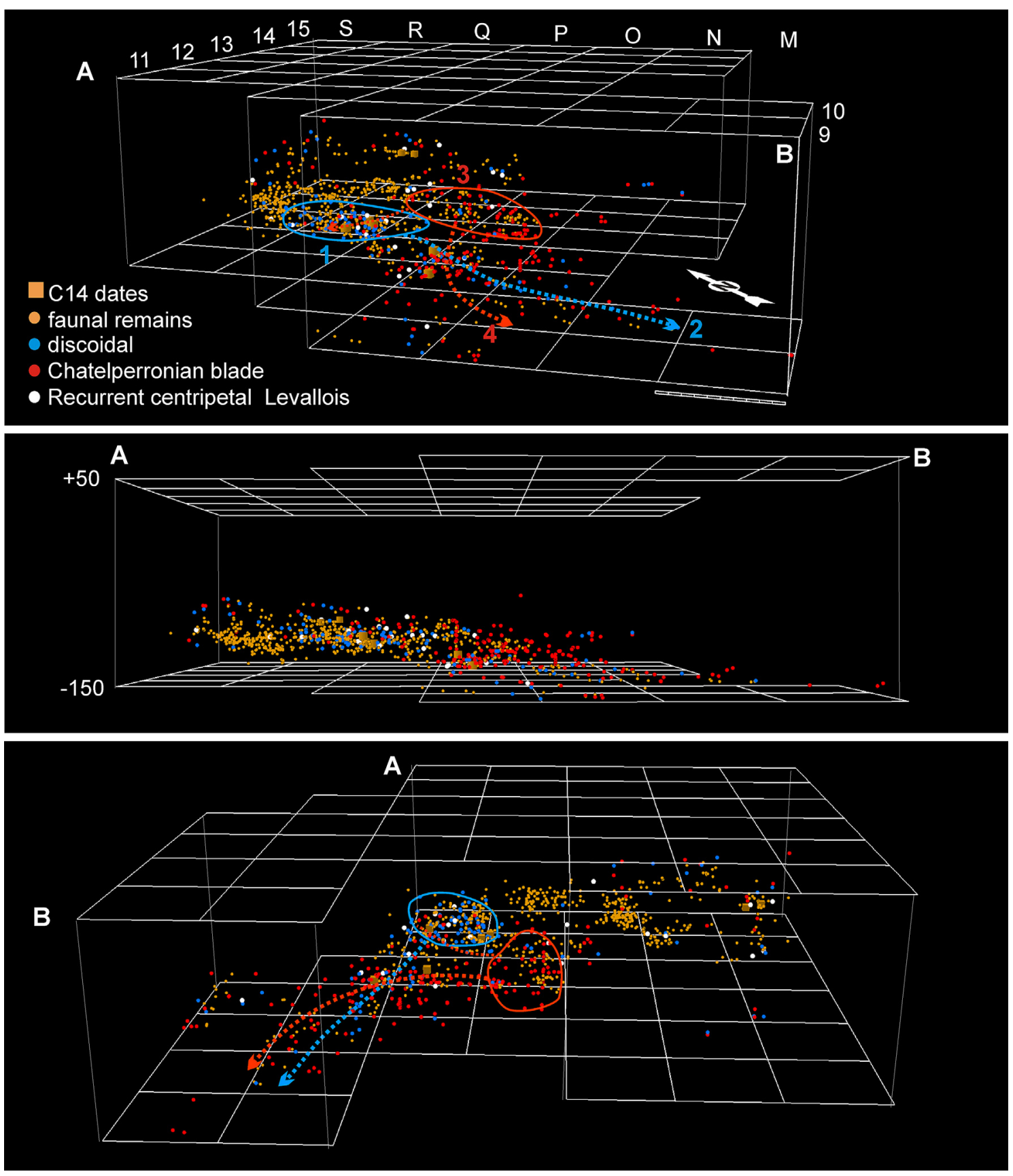

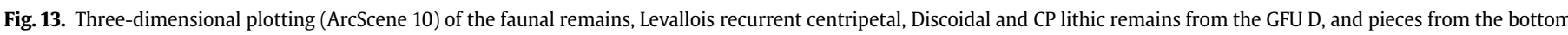
of the GFU E related by refitting (L. Luís).

more probable is of an incomplete decontamination of recent carbon during the pretreatment applying Langin protocol (Longin, 1971), confirming that most of the samples beyond $35 \mathrm{ka}$ dated by this conventional pretreatment are underestimated (Higham, 2011).

The age of $41,900 \pm 1500{ }^{14} \mathrm{C}$ yr BP $(48,976-43,101$ [95.4\%] cal yr BP) obtained for a large bovid bone fragment from the GFU D1 (Table 3 ) gives a terminus post quem for the collapse event $\mathrm{c} 2$ that occurred between a Levallois and Discoidal occupations.

The GFU D2 ages obtained by the ultrafiltration protocol on bone and tooth are in the interval from 40,5 to $48 \mathrm{ka}$ cal yr BP (Table 3 ). The ${ }^{14} \mathrm{C}$ calibrated ages range is consistent standard multi-grain quartz and K-rich feldspar (pIRIR 290 ) OSL measurements (Table 4) and additional single-grain quartz results, (Thomsen et al., submitted for publication). The GFU D2 samples are dated by OSL on multi-grain quartz to the 39.5-46 ka interval, and on feldspar to the 44.5-48.5 ka interval (Table 4).

The large interval for the ${ }^{14} \mathrm{C}$ ages obtained by the ultrafiltration protocol from the GFU D2 (Table 3) could be explained by their relationship with distinct human occupations of the Bordes-Fitte rockshelter (Fig. 4). The distribution of ${ }^{14} \mathrm{C}$ samples dated by the ultrafiltration protocol and lithics reveals that four bones from the 48-42 cal yr BP interval correspond to Discoidal remains, and the tooth sample dated from the $43-40.5$ cal yr BP range (OxA-22342) is associated to the $\mathrm{CP}$ remains distribution (Figs. 12 and 13). .

A terminus ante quem for $\mathrm{CP}$ occupation is provided by the ages of $34,520 \pm 850{ }^{14} \mathrm{C}$ yr BP $(41,095-36,925$ [95.4\%] cal yr BP) obtained on ultrafiltered bone collagen and $35,770 \pm 380{ }^{14} \mathrm{C}$ yr BP 
Table 3

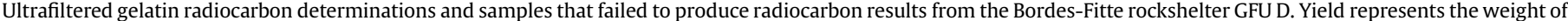

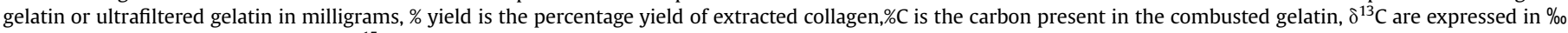

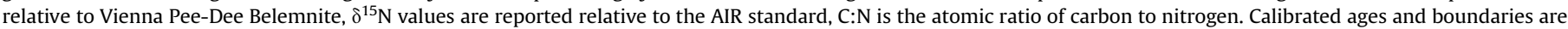
calculated by using OxCal 4.2 (Bronk Ramsey, 2013) and IntCal13 (Reimer et al., 2013).

\begin{tabular}{|c|c|c|c|c|c|c|c|c|c|c|c|c|c|c|c|}
\hline \multirow[t]{2}{*}{ OxA n } & \multirow[t]{2}{*}{ Sample reference } & \multirow[t]{2}{*}{ Stratigraphy } & \multirow[t]{2}{*}{ Material } & \multirow[t]{2}{*}{ Species } & \multirow[t]{2}{*}{ Used (mg) } & \multirow[t]{2}{*}{ Yield (mg) } & \multirow[t]{2}{*}{$\%$ Yld } & \multirow[t]{2}{*}{$\% \mathrm{C}$} & \multirow[t]{2}{*}{ d13C } & \multirow[t]{2}{*}{$\mathrm{d} 15 \mathrm{~N}$} & \multirow[t]{2}{*}{$\mathrm{C}: \mathrm{N}$} & \multirow[t]{2}{*}{$\begin{array}{l}{ }^{14} \mathrm{C} \text { age } \\
\mathrm{BP}\end{array}$} & \multirow[t]{2}{*}{$+1-$} & \multicolumn{2}{|c|}{$\begin{array}{l}\text { Calibrated age } \\
\text { range ( } 95.4 \% \text { prob.) }\end{array}$} \\
\hline & & & & & & & & & & & & & & From & To \\
\hline 26.470 & LRA 11 Q12A n63 & GFU D2 & Bone & $\begin{array}{l}\text { Equus } \\
\text { cabalus }\end{array}$ & 690 & 41.12 & 6 & 44.9 & -20.4 & 4.8 & 3.2 & 39.100 & 1.000 & 44.960 & 41.750 \\
\hline 26.471 & LRA 11 Q11B n²39 & GFU D2 & Bone & Bovid & 640 & 27.3 & 4.3 & 44 & -19.7 & 5.7 & 3.2 & 41.000 & 1.300 & 47.594 & 42.610 \\
\hline 26.472 & LRA 09 Q11A n²76 & GFU D2 & Bone & $\begin{array}{l}\text { Equus } \\
\text { cabalus }\end{array}$ & 680 & 14.57 & 2.1 & 44.1 & -20.2 & 5.4 & 3.2 & 40.600 & 1.200 & 46.778 & 42.455 \\
\hline 22.316 & LRA 09 P10B n¹55 & GFU D2 & Bone & $\begin{array}{l}\text { Rangifer } \\
\text { tarandus }\end{array}$ & 530 & 21.46 & 4 & 45.4 & -19.7 & 5.1 & 3.2 & 41.200 & 1.300 & 47.804 & 42.739 \\
\hline 22.342 & LRA 09 P11A n³07 & GFU D2 & Tooth & $\begin{array}{l}\text { Equus } \\
\text { caballus }\end{array}$ & 1050 & 21.96 & 2.1 & 41.7 & -21.0 & 4.9 & 3.1 & 37.400 & 800 & 43.046 & 40.446 \\
\hline \multirow[t]{3}{*}{29.527} & LRA 13 R15A n³5 & GFU D1 & Bone & Bovid & 610 & 8.41 & 1.4 & 43.4 & -20.1 & 5.5 & 3.3 & 41.900 & 1.500 & 48.976 & 43.101 \\
\hline & LRA 09 P10D n¹10 & GFU D2 & Bone & Megaloceros & \multicolumn{11}{|c|}{ Failed on \%N (0.4\%) } \\
\hline & LRA 13 R15C no 8 & GFU D2 & Tooth & $\begin{array}{l}\text { Equus } \\
\text { caballus }\end{array}$ & \multicolumn{11}{|c|}{ Failed due to low yield } \\
\hline
\end{tabular}

(41,279-39,574 [95.4\%] cal yr BP), on bone collagen using the Longin method (Longin, 1971), both recovered at the bottom of the GFU E (Fig. 3, Aubry et al., 2012). Considering blade and bladelet technology of the GFU E lithic assemblage, and radiocarbon age range obtained by ultrafiltration on samples from Early Aurignacien occupations (Higham et al., 2010, 2011; Talamo et al., 2012), the date obtained on a bone using collagen extracted with alkali preparation to $35,770 \pm 380{ }^{14} \mathrm{C}$ yr BP is probably underestimated (Higham et al., 2006), and could correspond to a CP occupation remains reworked in GFU E, as attested by the CP refits where GFU $\mathrm{D}$ is not capped by a collapsed roof fragment (Fig. 13).

Excluding the incoherent radiocarbon ages from the samples prepared by the Longin protocol and considering that multi-grain quartz 092201 and 092202 gave an estimation of the Discoidal and CP occupations, we have built a Bayesian model (Bronk Ramsey, 2009, Fig. 14) for the distribution of ages using the OxCal 4.2 (Bronk Ramsey, 2013) and the INTCAL13 curve (Reimer et al., 2013). This model, using the taphonomical and stratigraphical information, is based on the distinction of a sequence of four phases in the Bordes-Fitte rock-shelter sequence (preliminary OSL ages for the Middle Palaeolithic occupations of the GFU B and C and Solutrean radiocarbon and OSL ages of the GFU F (Aubry et al., 2012, Table 4) were not included in this model), which take into account the techno-typological data and refits. These phases are the centripetal or preferential recurrent Levallois with side-scrapers Middle Palaeolithic (GFU D1), Discoidal/Denticulate Middle Palaeolithic (GFU D2 bottom), Châtelperronian (GFU D2 top), and the Aurignacian (GFU E). The convergence value for the LRA-Bordes-Fitte rockshelter model is high (99.35) suggesting a robust model. The model obtained places the GFU D1-3 deposition in the Heinrich Stadial 5 to 4 interval (Sanchez-Goñi and Harrison, 2010) and Châtelperronian/Aurignacian boundary fits perfectly with the upper limit of the Mousterian and Châtelperronian proposed recently by Higham et al. (2014), based on AMS ages obtained by the ultrafiltration protocol from several MUP sequences of France. New radiocarbon measurements using the ultrafiltration protocol are proceeding for samples from the GFU E, in order to test the existence of two Aurignacian phases.

\section{Implication for the Late Middle and Early Upper Palaeolithic timing and variability in Western Europe}

Reappraising lithic assemblages from Late Middle Palaeolithic stratified sequences of Southern France, Jaubert et al. (2011) have proposed that the Mousterian of Acheulean Tradition (MTA) and CP could be separated by two LMP phases, questioning the MTA-CP direct filiation model (Bordes, 1971; Pelegrin, 1995). The first one would be characterized by Denticulate tools on Discoidal debitage, following the MTA in several sequences (Thiébaut, 2007). The second would be a "Levallois Mousterian with large scrapers", underlying Discoidal-Denticulate assemblages, which has been proposed as a possible ending phase for the LMP in South-western France (Jaubert et al., 2011). Based on typo-technological and chrono-stratigraphy, this LMP phase has been identified at Les Rochers-de-Villeneuve, Roc de Combe, La Quina, Le Moustier, Saint Césaire, the Grotte du Bison and Galerie Schoepflin at Arcy-surCure.

Levallois assemblages are overlying Discoidal levels at the top of the Middle Palaeolithic sequence of the Grotte du Bison and Galerie Schoepflin at Arcy-sur-Cure (Girard, 1982; Girard et al., 1990; Jaubert et al., 2011). Such occupations are dated on ultrafiltered bone collagen of samples from layer J at Les Rochers-de-Villeneuve to $45,200 \pm 1100{ }^{14} \mathrm{C}$ yr BP $(\mathrm{OxA}-15257)$, from $37,600 \pm 900{ }^{14} \mathrm{C} \mathrm{yr}$ $\mathrm{BP}$ (OxA-2300-19), 40,600 $\pm 1800{ }^{14} \mathrm{C}$ yr BP (OxA-21765),

Table 4

Synthesis of OSL multi-grain ages on quartz and feldspar for the Bordes-Fitte rockshelter.

\begin{tabular}{|c|c|c|c|c|c|c|c|c|c|c|}
\hline Site & GFU & Field reference & Lab code & Depth, cm & Mineral & Age, ka & Dose, Gy & $(\mathrm{n})$ & Dose rate, Gy/ka & w.c. (\%) \\
\hline Bordes-Fitte rockshelter & $\mathrm{F}$ & LRA-BF 09 P12A S2 & 092203 & 170 & Quartz & $22.7 \pm 1.3$ & $72.2 \pm 2$ & 74 & $3.19 \pm 0.15$ & 4 \\
\hline Bordes-Fitte rockshelter & & LRA-BF 09 P12A S2 & & & Feldspar & $24.9 \pm 1.2$ & $100 \pm 2$ & 9 & $4.00 \pm 0.16$ & 4 \\
\hline Bordes-Fitte rockshelter & $\mathrm{F}$ & LRA-BF 09 N11A S3 & 092204 & 150 & Quartz & $26.2 \pm 1.5$ & $69 \pm 2$ & 66 & $2.64 \pm 0.13$ & 1 \\
\hline Bordes-Fitte rockshelter & & LRA-BF 09 N11A S3 & & & Feldspar & $28.2 \pm 1.4$ & $97 \pm 3$ & 9 & $3.45 \pm 0.14$ & 1 \\
\hline Bordes-Fitte rockshelter & D2 & LRA-BF 09 P10A S4 & 092201 & 200 & Quartz & $43.7 \pm 2.2$ & $109 \pm 2$ & 63 & $2.49 \pm 0.11$ & 2 \\
\hline Bordes-Fitte rockshelter & D2 & LRA-BF 09 P10A S1 & 092202 & 200 & Quartz & $41.9 \pm 2.3$ & $106 \pm 3$ & 50 & $2.54 \pm 0.12$ & 3 \\
\hline Bordes-Fitte rockshelter & D2 & LRA-BF 09 P10A S1 & & & Feldspar & $46.5 \pm 1.9$ & $156 \pm 3$ & 8 & $3.35 \pm 0.13$ & 3 \\
\hline
\end{tabular}

Note: $(\mathrm{n})$ denotes the number of aliquots contributing to the dose. 


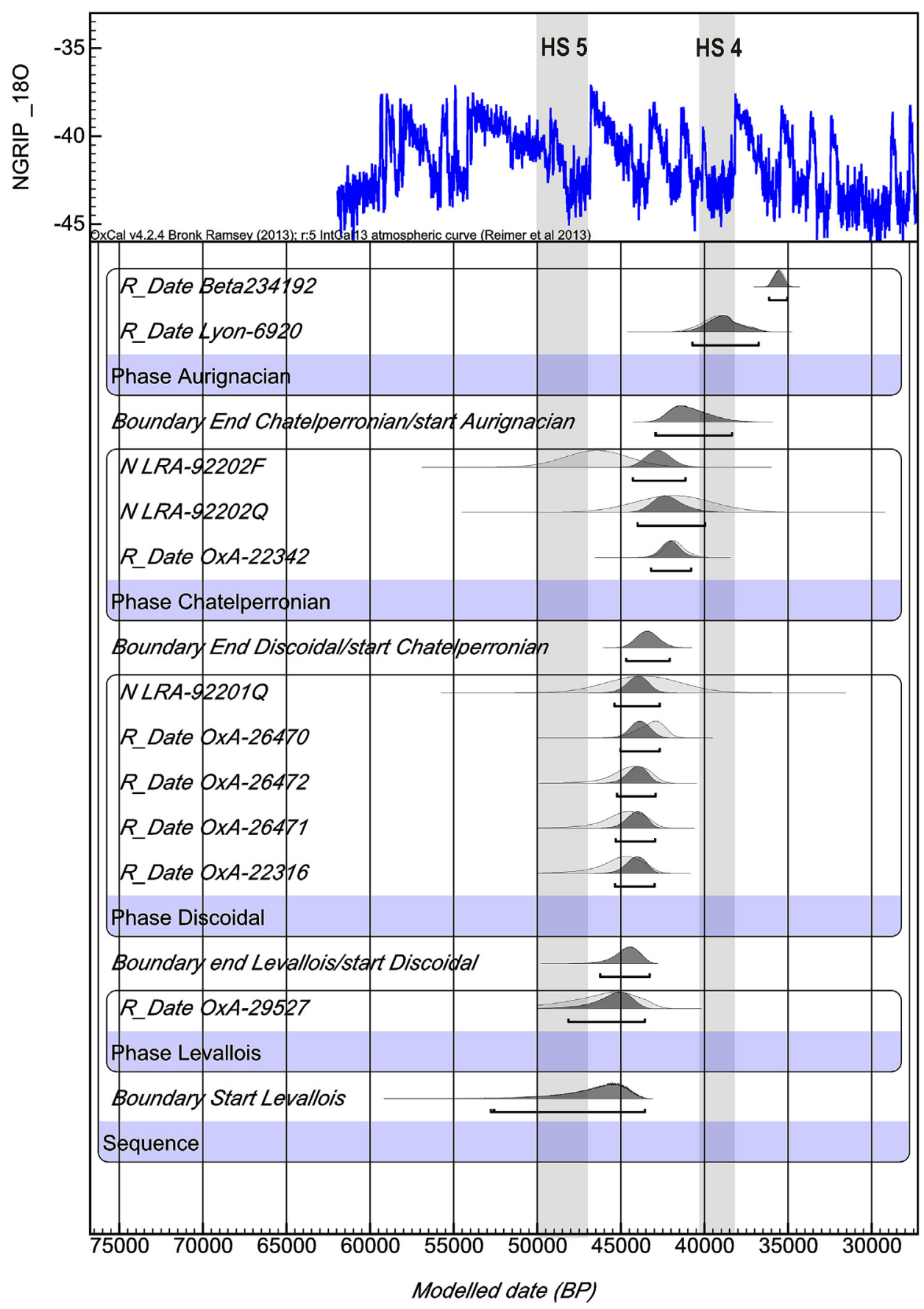

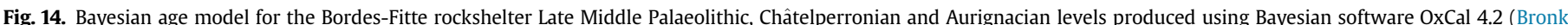

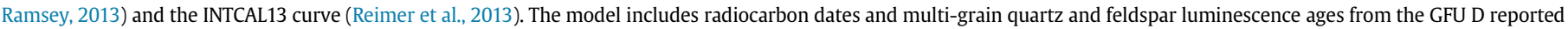
in Tables 3 and 4, and radiocarbon dates published previously (Aubry et al., 2012). Shaded areas are Heinrich events 4 and 5 (Sanchez-Goñi and Harrison, 2010).

$40,700 \pm 1300{ }^{14} \mathrm{C}$ yr BP (OxA-2300-21) to $45,100 \pm 2300{ }^{14} \mathrm{C}$ yr BP (OxA-21754) in the level $\mathrm{J}$ at Le Moustier, and to $41,100 \pm 1300{ }^{14} \mathrm{C}$ yr BP (OxA-21805) in the level 5 at La Quina Amont (Higham et al., 2014).

At the Bordes-Fitte rockshelter, spatial analysis and refitting of lithic remains reveal that the Levallois with large side-scrapers assemblage recovered in GFU D1 is separated by a roof collapse event from the Discoidal and CP occupations of GFU D2. Stratigraphy and the age obtained for the GFU D1 do not confirm an ending position for the Levallois Mousterian with large sidescrapers of the chrono-stratigraphical model proposed by Jaubert et al. (2011). Moreover, the ages obtained by TL of $44.8 \pm 3.4 \mathrm{ka}$ and $49.9 \pm 3.1$ ka for the Discoidal assemblage recovered at Les Bossats at Ormesson open air site (Bodu et al., 2013), the radiocarbon age obtained for the Denticulate on Discoidal debitage of Egpf level at Saint-Césaire (Higham et al., 2014) and of the level XI at the Grotte du Renne (Hublin et al., 2012), compare with the age range obtained for the Levallois with large side-scraper occupations, do not reveal a clear chrono-stratigraphical pattern, and confirm that the LMP sequence corresponding to the Heinrich Stadial 5 to 4 interval have yet to be established.

Technological study and the lack of refits between the Discoidal and $\mathrm{CP}$ remains recovered from the same geoarchaeological field sub-unit D2 at LRA-BF do not provide any evidence of continuity 
between the two reduction sequences. Moreover, the spatial distribution of the two technologies (Figs. 11 and 12) and 3D plotting (Fig. 13) indicate differential post-depositional displacement processes, separated by a wall fall event, and different degrees of preservation (Table 2 ).

The comparison with other MUP sequences dated by accelerator mass spectrometry radiocarbon on ultrafiltered bone collagen and the LRA-BF Bayesian model (Fig. 14) corroborate the age range of $45,000-41,000 \mathrm{cal}$ BP for the end of the Discoidal phase and the emergence of the Châtelperronian proposed by Higham et al. (2014). However, the data also indicate that the ages associated with the Discoidal occupation of the LRA-BF are statistically equivalent to the oldest dates of the CP layers Xc-a at the Grotte du Renne (Hublin et al., 2012; Higham et al., 2010, 2014). Such a fact could be explained by large statistical error in the ages obtained for this period, or could indicates that the use Middle Palaeolithic flake-based and CP point blank technology have been contemporaneous in different regions of France and Spain (Higham et al., 2014). Another possible explanation is that the long chronological interval proposed for the $\mathrm{CP}(45-41 \mathrm{ka})$, resulting essentially from the Grotte du Renne level X ages, could result from the mixing of LMP bone remains in this $\mathrm{CP}$ occupations. The analysis of diagnostic lithic and bone tools distribution has shown that vertical mixing between Grotte du Renne levels is not statistically proved (Caron et al., 2011). However, the spatial pattern and inter-level refits between the sub-layers X of the Grotte du Renne present some arguments supporting complex periglacial slope deposit processes in the formation of the site (Bar-Yosef and Bordes, 2010; Bertran et al., 2010). An LMP occupation could have occurred after the erosional unconformity attested by the irregular topography of the longitudinal section of layer XI (Connet, 2002:24), and changes in the sedimentary dynamics of the layer Xbis, deposited in a humid environment (Girard et al., 1990). Reworked lithic and faunal materials could be at the origin of the Middle Palaeolithic technological component recovered in layer X and IX and correspond to the oldest dates. This human occupation, only recorded in the sequence by remains in secondary position, could be contemporaneous with the Grotte du Bison's layer G/F/E (Girard, 1982).

At la Roche à Pierrot, the other site that could indicate a transitional character for CP stone tool assemblages (Bachellerie, 2011; Soressi, 2011), species distribution and faunal refits do not show inter-level mixing (Morin et al., 2005). The direct date of $36,200 \pm 750{ }^{14} \mathrm{C}$ yr BP (OxA-18099) obtained by ${ }^{14} \mathrm{C}$ using an ultrafiltration protocol on the Neanderthal tibia from Ejop sup (Hublin et al., 2012), yielding $0.77 \%$ of collagen, corresponds to the upper limit of the CP ages range proposed by Higham et al. (2014). The direct dating, contradicting the attribution of the Ejop sup occupation to an early phase of the CP (Lévêque et al., 1994), has been interpreted as an argument that the Roche à Pierrot's Ejop sup is contemporary with the most recent CP level VIII of the Grotte du Renne, and with the earliest likely modern humans remains documented in western Europe (Hublin et al., 2012). The ages obtained recently for 3 bone samples from the Ejop sup level, of $36,000 \pm 700{ }^{14} \mathrm{C}$ yr BP (OxA-21699), 36,650 $\pm 750{ }^{14} \mathrm{C}$ yr BP (OxA$21700)$ and $37,200 \pm 1000{ }^{14} \mathrm{C}$ yr BP (OxA-21636) are statistically equivalent to the direct date obtained on the Neanderthal tibia (Higham et al., 2014). Radiocarbon measurements and the possible existence of a burial pit attested by a lack of stones in the immediate context of the skeleton (Vandermeersch, 1993; Zilhão, 2013), are strong arguments to reject the hypothesis of an association of the Saint-Césaire Neanderthal with one of the Discoidal and Levallois lithic components attested in Ejop sup (Bachellerie, 2011), as proposed by Bar-Yosef and Bordes (2010), and to confirm the relationship of the Neanderthal skeleton with the CP lithic component of this level (Lévêque and Vandermeersch, 1980).

\section{Conclusions}

Sedimentary dynamics reconstruction, technological study and lithic refitting revealed that Levallois, Discoidal and CP stone tool assemblages recovered in the Bordes-Fitte rockshelter's GFU D1 and D2, result from successive occupations, separated by wall and roof collapse events, and affected by successive natural postdepositional displacement processes during the abrupt climatic oscillations of the Heinrich 5 to 4 interval (Fig. 14). Radiocarbon and luminescence ages obtained for the GFU D sub-layers, compared with other MUP sequences recently dated (Higham et al., 2014) confirm that at least a recurrent centripetal (and possibly preferential) Levallois and a Discoidal phase exist between the MTA and CP. Despite recent radiocarbon dating of Late Middle Palaeolithic occupations, the lack of taphonomical data concerning associated faunal and lithic assemblages do not permit to establish an accurate and definitive crono-stratigraphical framework of the Middle Palaeolithic occupations post-dating the MTA.

The technological variability of some of the $\mathrm{CP}$ assemblages, and the 45 to 41 ka probability distribution function for the beginning and the end of this technocomplex proposed by Higham et al. (2014), could be explained by the existence of transitional industries within the same human community, the coexistence of distinct lithic technologies in the same time period, or by a bias resulting of an environmental context favorable to the formation of accumulative palimpsests.

Considering that Middle Palaeolithic flake-based technology always precedes $\mathrm{CP}$ blade point production when present in the same stratigraphical sequence, the technological homogeneity of all the CP lithic industries recovered in single occupation level of open-air sites, the low resolution of ${ }^{14} \mathrm{C}$ beyond $35 \mathrm{ka}$ and OSL dating methods, independent age control investigation must be developed (Thomsen et al., submitted for publication). The different hypothesis should be tested applying a methodology susceptible to distinguish anthropogenic and non-anthropogenic processes in the formation of the archaeo-stratigraphic records in order to establish the exact relationship between samples dated and human or carnivore's occupation remains.

Untangling human and others contributions in site formation processes is still a crucial step regarding the elaboration of an accurate timeline and to establish the nature and cause of behavioral changes and relationship with the replacement processes of $\mathrm{Ne}-$ anderthals by modern humans in Western Europe.

\section{Acknowledgments}

Field work and analyses were supported by the Service Régional de l'Archéologie de la Région Centre (French Ministry of Culture). We thank the Smith family, owners of the Roches d'Abilly site, who kindly authorized the archaeological field work, Samantha Porter for constructive comments on an earlier version of the manuscript, Luís Luís for stimulating discussions and helpful remarks and the two anonymous reviewers for their for their useful suggestions for the improvement of the manuscript.

\section{References}

Aitken, M.J., 1985. Thermoluminescence Dating. Academic Press, London.

Aitken, M.J., 1998. An Introduction to Optical Dating. Oxford University Press, Oxford.

Angelucci, DE, 2002. The geoarchaeological context. In: Zilhão, J. Trinkaus, E. (Eds.), Portrait of the Artist as a Child. The Gravettian Human Skeleton from the Abrigo Do Lagar Velho and its Archaeological Context, Trabalhos de Arqueologia, vol. 22, pp. 58-91.

Aubry, T., 1991. L'exploitation des ressources en matières premières lithiques dans les gisements solutréens et badegouliens du bassin versant de la Creuse (France). Phd dissertation. University of Bordeaux I. 
Aubry, T., Dimuccio, L.A., Almeida, M., Buylaert, J.P., Fontana, L., Higham, T., Liard, M., Murray, A., Neves, M.J., Peyrouse, J.B., Walter, B., 2012. Stratigraphic and technological evidences from the Middle Palaeolithic-Châtelperronian-Aurignacian record at the Bordes-Fitte rockshelter (Roches d'Abilly site, Central France). J. Hum. Evol. 62, 116-137.

Bachellerie, F., 2011. Quelle unité pour le Châtelperronien ? : apport de l'analyse taphonomique et techno-économique des industries lithiques de trois gisements aquitains de plein air : le Basté, Bidart (Pyrénées-Atlantiques) et Canaule II (Dordogne). Phd dissertation. University of Bordeaux I.

Bachellerie, F., Bordes, J.G., Morala, A., Pelegrin, J., 2008. Étude typo-technologique et spatiale de remontages lithiques de Canaule II, site Châtelperronien de pleinair en Bergeracois. Paléo 19, 259-280.

Backer, A.M., 1993. Spatial distributions at la Roche-à-Pierrot, Saint-Césaire: changing uses of a rockshelter. In: Lévêque, F. (Ed.), Context of a Late Néandertal: Implications of Multidiciplinarity Research for the Transition to Upper Palaeolithic Adaptations at Saint-césaire, Charente-maritime, France, Monographs in World Archaeology, vol. 16, pp. 103-127.

Bailey, G., 2007. Time perspectives, palimpsests and the archaeology of time. J. Anth. Archaeol. 26, 198-223.

Banerjee, D., Murray, A.S., Bøtter-Jensen, L., Lang, A., 2001. Equivalent dose estimation using a single aliquot of polymineral fine grains. Rad. Mea 33, 73-94.

Bar-Yosef, O., Bordes, J.G., 2010. Who were the makers of the Chatelperronian culture? J. Hum. Evol. 59 (5), 586-593.

Bertran, P., Hetu, B., Texier, J.P., Van Steijn, H., 1997. Fabric characteristics of slope deposits. Sedimentology 44, 1-16.

Bertran, P., Klaric, L., Lenoble, A., Masson, B., Vallin, L., 2010. The impact of periglacial processes on Palaeolithic sites: the case of sorted patterned grounds. Quat. Int. 214, 17-29.

Bodu, P., 1990. L'application de la méthode des remontages à l'étude du matériel des premiers niveaux châtelperroniens de la Grotte du Renne à Arcy-surCure. In: Farizy, C. (Ed.), Paléolithique moyen récent et Paléolithique supérieur ancien en Europe. Actes du colloque International, Nemours 9-11 mai 1988, Mémoires du Musée de Préhistoire d'Ile-de-France, 3.

Bodu, P., Salomon, H., Leroyer, M., Naton, H.G., Lacarriere, J., Dessoles, M., 2013. An open-air site from the recent Middle Palaeolithic in the Paris Basin (France): les Bossats at Ormesson (Seine-et-Marne). Quat. Int. 331, 39-59.

Boëda, E., 1993. Le débitage Discoïde et le débitage Levallois récurrent centripète. Bull. Soc. Préhist. Fr. 90 (6), 392-404.

Boëda, E., 1994. Le concept Levallois : variabilité des méthodes. Monographie du CRA, Paris, CNRS éd.

Bordes, F., 1971. Du Paléolithique moyen au Paléolithique supérieur, continuité ou discontinuité ?. In: Origines de l'homme moderne, actes du colloque de l'Unesco, Paris, pp. 211-218.

Bordes, J.G., 2003. Lithic taphonomy of the Chattelperronian/Aurignacian interstratifications in Roc de Combe and Le Piage (Lot, France). In: Zilhão, J., d'Errico, F. (Eds.), The chronology of the Aurignacian and of the transitional technocomplexes. Dating, stratigraphies, cultural implications, 1990, Lisbonne : Instituto Português de Arqueologia, pp. 223-244.

Brantingham, P.J., Todd, A., Surovell, T.A., Waguespack, N.A., 2007. Modeling postdepositional mixing of archaeological deposits. J. Anthropol. Archaeol. 26, 517-540.

Brock, F., Higham, T.F.G., Ditchfield, P., Bronk Ramsey, C., 2010. Current pretreatment methods for AMS radiocarbon dating at the Oxford Radiocarbon Accelerator Unit (ORAU). Radiocarbon 52 (1), 103-112.

Bronk Ramsey, C., 2009. Bayesian analysis of radiocarbon dates. Radiocarbon 51 (1), 337-360.

Bronk Ramsey, C., 2013. OxCal 4.2. http://c14.arch.ox.ac.uk/oxcal.

Bullock, P.N., Fedoroff, N., Jongerius, G.J., Stoops, G., Tursina, T., Babel, U., 1985 Handbook for Soil Thin Section Description. Waine Research Publishers, Wolverhampton, U.K.

Buylaert, J.P., Jain, M., Murray, A.S., Thomsen, K.J., Thiel, C., Sohbati, R., 2012. A robust feldspar luminescence dating method for Middle and Late Pleistocene sediments. Boreas 41 (3), 435-451.

Caron, F., d'Errico, F., Del Moral, P., Santos, F., Zilhão, J., 2011. The reality of Neandertal symbolic behavior at the Grotte du Renne, Arcy-sur-Cure, France. PLoS ONE 6 (6), e21545.

Connet, N., 2002. Le Châtelperronien: Réflexion sur l'unité et l'identité Technoéconomique de l'industrie lithique: L'apport d'analyse Diachronique des Industries lithiques des couches châtelperroniennes de la Grotte du renne à Arcysur-Cure (Yonne). Phd dissertation. University of Lille 1.

Courty, M.-A., Goldberg, P., Macphail, R.I., 1989. Soils and Micromorphology in Archaeology. Cambridge University Press, Cambridge, U.K.

D'Errico, F., Zilhão, J., Julien, M., Baffier, D., Pelegrin, J., 1998. Neanderthal acculturation in western Europe? A critical review of the evidence and its interpretation. Curr. Anthropol. 12, 188-202.

Dibble, H.L., Bar-Yosef, O., 1995. The Definition and Interpretation of Levallois Technology. Prehistory Press.

Discamps, E., Delagnes, A., Lenoir, M., Tournepiche, J.M., 2012. Human and Hyena co-occurrences in pleistocene sites: Insights from spatial, faunal and lithic analyses at Camiac and La Chauverie (SW France). J. Taphon. 10 (3/4), 291-316.

FAO-Isric, 1990. Guidelines for Soil Description, third ed. FAO, Roma.

Girard, C., 1982. Les industries moustériennes de la grotte du Bison à Arcy-sur-Cure (Yonne). Gallia Préhistoire 25 (1), 107-129.

Girard, M., Miskovsky, J.C., Evin, J., 1990. La fin du Würm moyen et le début du Würm supérieur à Arcy-sur-Cure (Yonne). Précisions paléoclimatiques et chronostratigraphiques d'après les remplissages des grottes. In: Farizy, C. (Ed.), Paléolithique moyen récent et Paléolithique supérieur ancien en Europe, pp. 295-303. Actes du colloque International, Nemours 9-11 mai 1988, Mémoires du Musée de Préhistoire d'Ile-de-France, 3.

Goldberg, P., Macphail, R.I., 2006. Practical and Theoretical Geoarchaeology. Blackwell Publishing, London.

Gouedo, J.M., 1990. Les technologies lithiques du Châtelperronien de la couche X de la Grotte du Renne d'Arcy-sur-Cure (Yonne). In: Farizy, C. (Ed.), Paléolithique moyen récent et Paléolithique supérieur ancien en Europe. Colloque international de Nemours, pp. 305-309. Actes du colloque International, Nemours 911 mai 1988, Mémoires du Musée de Préhistoire d'Ile-de-France, 3.

Gravina, B., Mellars, P., Bronk Ramsey, C., 2005. Radiocarbon dating of interstratified Neanderthal and early modern human occupations at the Châtelperronian type-site. Nature 438, 51-56.

Guérin, G., Mercier, N., Adamiec, G., 2011. Dose-rate conversion factors: update. Anc. TL 29 (1), 5-8.

Heinrich, H., 1988. Origin and consequences of cyclic ice rafting in the Northeast Atlantic Ocean during the past 130,000 years. Quat. Res. 29 (2), 142-152.

Higham, T., 2011. European Middle and Upper Palaeolithic radiocarbon dates are often older than they look: problems with previous dates and some remedies. Antiquity 85 (327), 235-249.

Higham, T.F.G., Jacobi, R.M., Basell, L., Bronk Ramsey, C., Chiotti, L., Nespoulet, R., 2011. Precision dating of the Palaeolithic: a new radiocarbon chronology for the Abri Pataud (France), a key Aurignacian sequence. J. Hum. Evol. 61 (5), 549-563.

Higham, T.F.G., Jacobi, R.M., Bronk Ramsey, C., 2006. AMS Radiocarbon dating of ancient bone using ultrafiltration. Radiocarbon 48 (2), 179-195.

Higham, T.F.G., Jacobi, R.M., Julien, M., David, F., Basell, L., Wood, R., Davies, W., Bronk Ramsey, C., 2010. Chronology of the Grotte du Renne (France) and implications for the context of ornaments and human remains within the Châtelperronian. Proc. Natl. Acad. Sci. U. S. A. 107 (47), 20234-20239.

Higham, T., Douka, K., Wood, R., Bronk Ramsey, C., Brock, F., Basell, L., Camps, M., Arrizabalaga, A., Baena, J., Barroso-Ruíz, C., Bergman, C., Boitard, C., Boscato, P., Caparrós, M., Conard, N.J., Draily, C., Froment, A., Galván, B., Gambassini, P., Garcia-Moreno, A., Grimaldi, S., Haesaerts, P., Holt, B., Iriarte-Chiapusso, M.J., Jelinek, A., Jordá Pardo, J.F., Maíllo-Fernández, J.M., Marom, A., Maroto, J., Menéndez, M., Metz, L., Morin, E., Moroni, A., Negrino, F., Panagopoulou, E., Peresani, M., Pirson, S., de la Rasilla, M., Riel-Salvatore, J., Ronchitelli, A., Santamaria, D., Semal, P., Slimak, L., Soler, J., Soler, N., Villaluenga, A., Pinhasi, R., Jacobi, R., 2014. The timing and spatiotemporal patterning of Neanderthal disappearance. Nature 512, 306-309.

Hofman, J.L., Enloe, J.G., 1992. Piecing Together the Past: Application of Refitting Studies in Archaeology. In: BAR International Series, vol. 578.

Howells, W.W., 1976. Explaining modern man. evolutionists versus migrationists. J. Hum. Evol. 5, 447-495.

Hublin, J.J., Talamo, S., Julien, M., David, F., Connet, N., Bodu, P., Vandermeersch, B., Richards, M.P., 2012. Radiocarbon dates from the Grotte du Renne and SaintCésaire support a Neandertal origin for the Châtelperronian. Proc. Natl. Acad. Sci. U. S. A. 109, 18743-18748.

Hüls, P.M., Grootes, M.J., Nadeau, M.J., 2007. How clean is ultrafiltration cleaning of bone collagen? Radiocarbon 49 (2), 193-200.

Huntley, D.J., Baril, M.R., 1997. The K content of the K-feldspars being measured in optical dating or in thermoluminescence dating. Anc. TL 15, 11-13.

Jacobi, R.M., Higham, T.F.G., Bronk Ramsey, C., 2006. AMS radiocarbon dating of Middle and Upper Palaeolithic bone in the British Isles: improved reliability using ultrafiltration. J. Quat. Sci. 21 (5), 557-573.

Jaubert, J., Bordes, J.G., Discamps, E., Gravina, B., 2011. A new look at the end of the middle palaeolithic sequence in Southwestern France. In: Derevianko, Shunkov (Eds.), Characteristic Features of the Middle to Upper Paleolithic Transition in Eurasia. Asian Palaeolithic Association, Novosibirsk, pp. 102-115.

Keeley, H.C.M., Macphail, R.I., 1981. A Soil Handbook for Archaeologists. Bull. Instit. Archaeol, London, pp. 225-243.

Laignel, B., Quesnel, F., Meyer, R., Bourdillon, C., 1999. Reconstruction of the Upper Cretaceous chalks removed by dissolution during the Cenozoic in the western Paris Basin. Int. J. Earth Sci. 88, 467-474.

Laughlin, J., Kelly, R.L., 2010. Experimental analysis of the practical limits of lithic refitting. J. Archaeol. Sci. 37 (2), 427-433.

Lenoble, A., Bertran, P., 2004. Fabric of Palaeolithic levels: methods and implications for site formation processes. J. Archaeol. Sci. 31, 457-469.

Lévêque, F., Backer, A.M., Guilbaud, M., 1994. Technological differentiation associated with the Saint-Césaire Neandertal. Préhistoire Eur. 6, 187-196.

Lévêque, F., Vandermeersch, B., 1980. Découverte de restes humains dans le niveau Castelperronien à Saint-Césaire (Charente-Maritime). C.R. Acad. S. C. Paris 291, 187-189.

Longin, R., 1971. New method of collagen extraction for radiocarbon dating. Nature 230, 241-242.

McPherron, S.J.P., 2005. Artifact orientations and site formation processes from total Station Proveniences. J. Archaeol. Sci. 32, 1003-1014.

McPherron, S.P., Talamo, S., Goldberg, P., Niven, L., Sandgathe, D., Richards, M.P., Richter, D., Turq, A., Dibble, H.L., 2012. Radiocarbon dates for the late Middle Palaeolithic at Pech de l'Azé IV, France. J. Archaeol. Sci. 39, 3436-3442.

Mellars, P.A., 1996. The Neanderthal Legacy: an Archaeological Perspective from Western Europe. Princeton University Press.

Mellars, P., 2005. The impossible coincidence. A single-species model for the origins of modern human behavior in Europe. Evol. Anthropol 14, 12-27. 
Médioni, M.R., Debrand-Passard, M.S., Perna, G., Weecksteen, M.M., 1974. Châtellerault. Carte Géologique de la France à 1/50000. Ministère de l'Industrie et de la Recherche, Service Géologique National, Paris.

Murray, A., Thomsen, K.J., Masuda, N., Buylaert, J.P., Jain, M., 2012. Identifying wellbleached quartz using the different bleaching rates of quartz and feldspar luminescence signals. Rad. Mea. 47 (9), 688-695.

Morin, E., Tsanova, T., Sirakov, N., Rendu, W., Mallye, J.B., Lévêque, F., 2005. Bone refits in stratified deposits: testing the chronological grain at Saint-Césaire. J. Archaeol. Sci. 32 (7), 1083-1098.

Murray, A.S., Marten, R., Johnston, A., Martin, P., 1987. Analysis for naturally occurring radionuclides at environmental concentrations by gamma spectrometry. J. Rad. Nuc. Chem. 115, 263-288.

Murray, A.S., Wintle, A.G., 2000. Luminescence dating of quartz using an improved single-aliquot regenerative-dose protocol. Rad. Mea 32, 57-73.

Murray, A.S., Wintle, A.G., 2003. The single aliquot regeneration dose protocol: potential for improvements in reliability. Rad. Mea 37, 377-381.

Nicod, J., 1994. Paléokarst et paléomorphologies dans le domaine méditerranéen (éléments de réflexion et discussion). Rev. Géogra. Maroc. 16, 309-333.

Pelegrin, J., 1995. Technologie lithique: le Châtelperronien de Roc-de-Combe (Lot) et de La Côte (Dordogne). Cahiers du Quaternaire 20. Editions CNRS, Paris.

Reimer, P.J., Bard, E., Bayliss, A., Beck, J.W., Blackwell, P.G., Bronk Ramsey, C., Buck, C.E., Edwards, R.L., Friedrich, M., Grootes, P.M., Guilderson, T.P., Haflidason, H., Hajdas, I., Hatté, C., Heaton, T.J., Hoffmann, D.L., Hogg, A.G. Hughen, K.A., Kaiser, K.F., Kromer, B., Manning, S.W., Niu, M., Reimer, R.W., Richards, D.A., Scott, E.M., Southon, J.R., Turney, C.S.M., van der Plicht, J., 2013. IntCal13 and Marine13 radiocarbon age calibration curves, 0-50,000 years cal BP. Radiocarbon 55, 1869-1887.

Richter, D., Dibble, H., Goldberg, P., McPherron, S.P., Niven, L., Sandgathe, D. Talamo, S., Turq, A., 2013. The late Middle Palaeolithic in Southwest France: new TL dates for the sequence of Pech de l'Azé I. Quat. Int. 294, 160-167.

Rigaud, J.P., 1996. L'émergence du Paléolithique supérieur en Europe occidentale. Le rôle du Castelperronien. In: Bar-Yosef, O., Cavalli-Sforza, L., Piperno, R.M. (Eds.) The Lower and Middle Palaeolithic. Forli, ABACO, pp. 219-223.

Rios-Garaizara, J., Arrizabalaga, A., Villaluenga, A., 2012. Haltes de chasse du Châtelperronien de la Péninsule Ibérique : Labeko Koba et Ekain (Pays Basque Péninsulaire). L'Anthropologie 116 (4), 532-549.

Roussel, M., 2011. Normes et Variations de la Production Lithique durant le Châtelperronien: La séquence de la Grande-Roche-de-la-Plématrie à Quinçay (Vienne). PhD thesis. Université Paris Ouest Nanterre-La Défense, Paris.

Sanchez-Goñi, M.F., Harrison, S.P., 2010. Millenial-scale climate variability and vegetation changes during the last Glacial: concepts and terminology. Quat. Sci. Rev. 29 (21-22), 2823-2827.
Soressi, M., 2011. Taphonomic and techno-typological revision of two assemblages attributed to Châtelperronian at Saint-Cesaire. L'Anthropologie 115 (5), 569-584.

Spooner, N.A., 1994. The anomalous fading of infrared-stimulated luminescence from feldspars. Rad. Meas. 23, 625-632.

Stoops, G., 2003. Guidelines for Analysis and Description of Soil and Regolith Thin Sections. Soil Science Society of America, Madison, WI.

Stoops, G., Marcelino, V., Mees, F., 2010. Interpretation of Micromorphological Features of Soils and Regoliths. Elsevier, Netherlands.

Talamo, S., Soressi, M., Roussel, M., Richards, M., Hublin, J.-J., 2012. A radiocarbon chronology for the complete Middle to Upper Palaeolithic transitional sequence of Les Cottés (France). J. Archaeol. S. C. 39, 175-183.

Thiébaut, C., 2007. Le Moustérien à denticulés des années 1950 à nos jours : définitions et caractérisation. Bull. Soc. Préhist. Fr. 104 (3), 461-481.

Thiel, C., Buylaert, J.P., Murray, A., Terhorst, B., Hofer, I., Tsukamoto, S., Frechen, M., 2011. Luminescence dating of the Stratzing loess profile (Austria) - testing the potential of an elevated temperature post-IR IRSL protocol. Quat. Int. 234, 23-31.

Thomsen, K.J., Murray, A.S., Jain, M., Bøtter-Jensen, L., 2008. Laboratory fading rates of various luminescence signals from feldspar-rich sediment extracts. Rad. Mea 43, 1474-1486.

Thomsen, K.J., Murray, A.S., Jain, M., 2011. Stability of IRSL signals from sedimentary K-feldspar samples. Geochronometria 38, 1-13.

Thomsen, K.J., Murray, A.S., Buylaert, J.P., Jain, M., Hansen, J.H., Aubry, T., 2014. Testing single-grain quartz OSL methods using sediment samples with independent age control from the Bordes-Fitte rockshelter (Roches d'Abilly site, Central France). Quat. Geochronol. submitted for publication.

Vandermeersch, B., 1993. Was the Saint-Césaire discovery a burial? In: Lévêque, F., Backer, A.M., Guilbaud, M. (Eds.), Context of a Late Neandertal. Prehistory, Madison, pp. 129-131.

Villa, P., 1982. Conjoinable pieces and site formation processes. Am. Antiq. 47, 277-290.

Villa, P., Soressi, M., 2000. Stone tools in carnivore sites: the case of Bois Roche. J. Anthropol. Res. 56 (2), 187-215.

Zilhão, J., d'Errico, F., Bordes, J.G., Lenoble, A., Texier, J.P., Rigaud, J.P., 2006. Analysis of Aurignacian interstratification at the Châtelperronian-type site and implications for the behavioral modernity of Neandertals. Proc. Natl. Acad. Sci. U. S. A. 103 (33), 12643-12648.

Zilhão, J., 2013. Neandertal-modern human contact in western Eurasia: Issues of dating, taxonomy, and cultural associations. In: Akazawa, T., et al. (Eds.), Dynamics of Learning in Neanderthals and Modern Humans, Cultural Perspectives, Replacement of Neanderthals by Modern Humans Series, vol. 1. Springer Japan, pp. $21-57$. 